\title{
Functional Diversity of Soil Nematodes in Relation to the Impact of Agriculture-A Review
}

\author{
Stela Lazarova ${ }^{1, *(\mathbb{D}}$, Danny Coyne ${ }^{2} \mathbb{D}$, Mayra G. $_{\text {Rodríguez }}^{3} \mathbb{D}$, Belkis Peteira ${ }^{3} \mathbb{D}$ and Aurelio Ciancio $^{4, *(\mathbb{D})}$ \\ 1 Institute of Biodiversity and Ecosystem Research, Bulgarian Academy of Sciences, 2 Y. Gagarin Str., \\ 1113 Sofia, Bulgaria \\ 2 International Institute of Tropical Agriculture (IITA), Kasarani, Nairobi 30772-00100, Kenya; \\ d.coyne@cgiar.org \\ 3 National Center for Plant and Animal Health (CENSA), P.O. Box 10, Mayabeque Province, \\ San José de las Lajas 32700, Cuba; mrguez@censa.edu.cu (M.G.R.); bpeteira@censa.edu.cu (B.P.) \\ 4 Consiglio Nazionale delle Ricerche, Istituto per la Protezione Sostenibile delle Piante, 70126 Bari, Italy \\ * Correspondence: stela.lazarova@iber.bas.bg (S.L.); aurelio.ciancio@ipsp.cnr.it (A.C.); \\ Tel.: +359-8865-32-609 (S.L.); +39-080-5929-221 (A.C.)
}

Citation: Lazarova, S.; Coyne, D.; Rodríguez, M.G.; Peteira, B.; Ciancio, A. Functional Diversity of Soil Nematodes in Relation to the Impact of Agriculture-A Review. Diversity 2021, 13, 64. https://doi.org/ $10.3390 / \mathrm{d} 13020064$

Academic Editors: Luc Legal and Patrice Bouchard

Received: 14 December 2020

Accepted: 28 January 2021

Published: 4 February 2021

Publisher's Note: MDPI stays neutra with regard to jurisdictional claims in published maps and institutional affiliations.

Copyright: (c) 2021 by the authors. Licensee MDPI, Basel, Switzerland. This article is an open access article distributed under the terms and conditions of the Creative Commons Attribution (CC BY) license (https:/ / creativecommons.org/licenses/by/ $4.0 /)$

\begin{abstract}
The analysis of the functional diversity of soil nematodes requires detailed knowledge on theoretical aspects of the biodiversity-ecosystem functioning relationship in natural and managed terrestrial ecosystems. Basic approaches applied are reviewed, focusing on the impact and value of soil nematode diversity in crop production and on the most consistent external drivers affecting their stability. The role of nematode trophic guilds in two intensively cultivated crops are examined in more detail, as representative of agriculture from tropical/subtropical (banana) and temperate (apple) climates. The multiple facets of nematode network analysis, for management of multitrophic interactions and restoration purposes, represent complex tasks that require the integration of different interdisciplinary expertise. Understanding the evolutionary basis of nematode diversity at the field level, and its response to current changes, will help to explain the observed community shifts. Integrating approaches based on evolutionary biology, population genetics and ecology can quantify the contribution of nematode fauna to fundamental soil functions. These include carbon transformation, nutrient cycling, pest control and disease transmission. In conclusion, different facets of nematode diversity such as trophic groups, life history traits, variability in body size and/or taxa identities in combination with DNA-based techniques are needed in order to disclose nematode-soil-ecosystem functioning relationships. Further experimental studies are required to define locally adapted and sustainable management practices, through ecosystem-based approaches and nature-based solutions.
\end{abstract}

Keywords: apple; banana; land use intensity; nematode community; Pratylenchus; Radopholus; soil biodiversity; soil ecosystem service; soil microbiome

\section{Introduction}

Biological diversity is the foundation of ecosystem processes (functions) and services. Climate and habitat changes, invasive alien species, overexploitation and pollution are the most important direct drivers of biodiversity loss and ecosystem service changes induced by human activities [1]. Approximately $60 \%$ of the world ecosystem services are considered as degraded or unsustainably used [2]. More than 75\% of Earth's ice-free land shows evidence of alteration as a result of land use and human habitation [3]. The land use and the associated loss of natural habitats were rated as the most important drivers of biodiversity decline in the terrestrial realm [4]. The changes showing marked spatial variation and future losses appear concentrated in biodiverse but economically poor countries [5]. The conversion of natural land from complex to simplified agricultural and forestry systems can have substantial, often strongly negative, effects on soil biological communities and their activities [6,7]. Croplands, pastures and permanent plantations are the predominant 
land uses related to agriculture, where the degree of intensity can range from minimal to intense. In general, conventional crop systems are characterized by simplified land cover, degraded soil, low organic matter (OM) content, more extreme wet-dry cycles and high residual nutrient levels. In particular, soil degradation results in accelerated erosion, soil habitat changes and biodiversity losses, induced by multiple agricultural practices, such as excessive tillage, inadequate residue management and excessive use of fertilizers and pesticides. We have, however, almost no information on species loss, biodiversity decline or composition shifts in soil communities, and the related impacts on ecosystem processes, such as primary production, biogeochemical cycles and decomposition [8].

Nematodes represent one of the largest phyla in the animal kingdom, both in terms of diversity and abundance. They have great genetic diversity and phenotypic plasticity that enables them to occupy a vast range of habitats. Nematodes are the most numerous soil-dwelling multicellular animals that feed and reproduce in the water film around and within soil aggregates. However, a small group of plant parasitic species spend a significant part or their lifecycle in roots. Being a widespread and diverse group, nematodes display a wide range of adaptations and functional traits that make them ideal for ecological and evolutionary biology studies. Moreover, they are involved in complex ecological networks through their interactions with other soil organisms, at multiple levels. The implementation of molecular methods, including next-generation sequencing (NGS), has greatly facilitated the study of nematode diversity, enabling new insights into our understanding of their distribution patterns [9-13].

This review focuses primarily on nematode functional diversity in terrestrial ecosystems. We first discuss the functional diversity concept in ecosystem ecology and some current understandings on the ecology of terrestrial nematodes related to their functional role, spatial distribution and community assembly. Experimental results and findings linking nematode functional diversity to human-induced changes are presented, taking as examples plant parasitic nematodes (PPN) or entomopathogens in two perennial crops with high impact, focusing on cover changes or agricultural intensity.

\section{Functional Diversity}

The biodiversity-ecosystem functioning relationship is one of the most explored topics in ecology. In general, scientists and conservationists measure species richness and diversity. However, recent studies and theoretical developments show that ecosystem processes depend heavily on the functional characteristics (traits) of the organisms present in an ecosystem [14,15] or functional diversity. It is defined as "the range and value of those species and organismal traits that influence ecosystem functioning" [16]. Moving from a taxonomic to a functional trait-based approach enables large-scale comparison of general patterns and principles across communities and ecosystems $[17,18]$. This approach allows us to understand how much trait diversity is necessary to maintain multiple ecosystem functions simultaneously (i.e., ecosystem multifunctionality), and to reveal the complex nature of the community changes and response to disturbance [19-22].

Ecosystem processes and services depend on the structure, function and dynamics of soil communities. To understand the relationships between soil biota and ecosystem services, the utility of the "functional groups" approach appears to be limited, as it fails to consider within-group variation in traits, underestimating the link between functional diversity and ecosystem functioning [23,24]. Functional groups are usually defined at one trophic level, and the relationship between such groups and ecosystem functioning is not always straightforward. The functional trait (physiological, morphological, behavioral, or phenological), is a well-defined property of organisms, usually measured at the individual level [15]. They affect fitness indirectly, via their impact on growth, reproduction and survival [25]. It is crucial to distinguish both the effect traits, i.e., the species traits that affect ecosystem functioning, and the response traits, that determine a species response to an environmental change [26]. 


\section{Nematode Functional Role, Functional Groups and Traits Diversity}

Studies on the role of nematode diversity are less represented when compared to the interactions involving plants, fungi or bacteria, which comprise the greatest number of studies currently available in the literature (Figure 1). This prevalence is also indicated by the wordcounts for biodiversity and nematode studies, as shown in Figure 2.

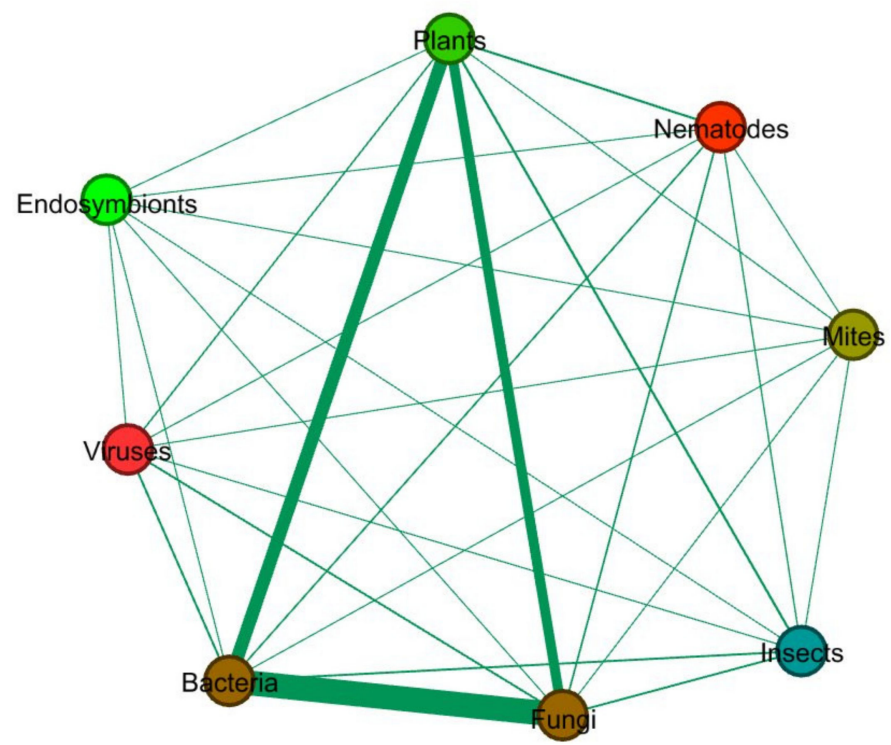

Figure 1. Number of publications with the keyword "biodiversity" indicated, for each node pair, by the edge thickness (data retrieved from PubMed, search period: 1947-2020; network produced with Gephi, https: / / gephi.org (accessed on 13 December 2020)).

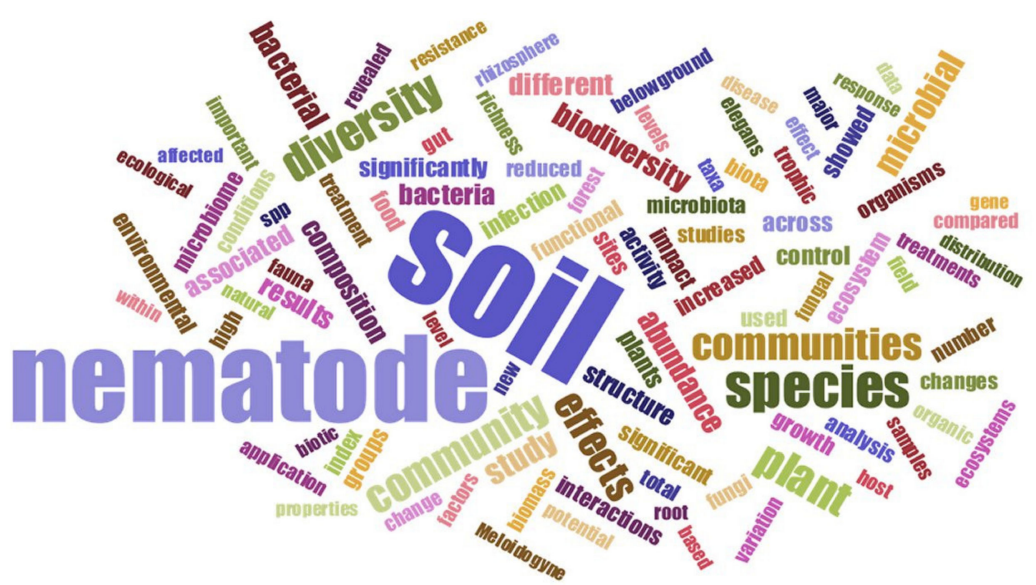

Figure 2. Most represented words in title and abstract of scientific papers with keywords "biodiversity", "soil" and "nematode" in title and/or abstract, published during the last five years (source: PubMed, produced at https:/ / www.jasondavies.com/wordcloud/ (accessed on 13 December 2020)).

Being an important component of soil food webs, nematodes have an essential role in all soil processes and ecosystem functions. They are involved in carbon (C) transformation and nutrient cycling originating from living plant roots ("direct pathway") and dead plant residues ("indirect pathway"). Through their metabolic and behavioral activity, nematodes contribute to plant growth and primary productivity, $\mathrm{C}$ and nutrient cycling, as well as pest and disease control, such as by entomopathogenic nematodes (EPN) [27]. Nematodes also indirectly contribute to decomposition of soil OM [11,28].

The functional grouping of nematodes is generally synonymous with their allocation into feeding groups, however the link between ecosystem functions and functional groups 
is not always straightforward or clear [23]. Different feeding groups can be involved in a given function (e.g., nematodes from all feeding groups contribute to the $\mathrm{C}$ transformation or nutrient cycling, directly or indirectly). The majority of free-living nematodes feed on bacteria and fungi, and their role can be direct, via the excretion of (in)organic compounds into soil, and indirect, by altering the size, composition and activity of the microbial community [29]. Microbial feeders can promote the competitive ability and dispersal of beneficial microbiota by selectively grazing on harmful soil microorganisms [30] or by transferring, as vectors, beneficial bacteria to the rhizosphere [31], and vice versa, harmful bacteria and viruses can also be transmitted in this way. Soil nematodes have developed numerous feeding strategies within each trophic group and a great variety of morphological structures used for food ingestion [11]. Dissecting the complex web of services resulting by nematodes' evolutionary history requires intense analytical efforts. A schematic summary of nematode functional roles is given in Table 1. The impact of nematode diversity and functional roles varies at different spatial scales, ranging from single root systems to cultivated field or wider space levels. Moreover, the activity of phylogenetically distant taxa may converge towards the same functional role. This trend is mirrored by species from the same taxonomic lineage (i.e., Tylenchida or Dorylaimida) that have distinct functional roles.

Table 1. A schematic list of nematode contributions to main soil functions and services provided by different trophic groups.

\begin{tabular}{|c|c|c|c|c|}
\hline \multirow{2}{*}{$\begin{array}{l}\text { Nematode Trophic } \\
\text { Groups }\end{array}$} & \multicolumn{4}{|c|}{ Functions* } \\
\hline & Plant Production & $\begin{array}{l}\text { Pests or Pathogens } \\
\text { Regulation }\end{array}$ & Disease Transmission & $\mathrm{C}$ and Nutrient Cycling \\
\hline Bacterial feeders & $\begin{array}{c}+/-(\text { vectors of } \\
\text { beneficial/harmful bacteria) }\end{array}$ & $\begin{array}{c}+ \text { (feeding on harmful } \\
\text { bacteria) }\end{array}$ & & + \\
\hline Fungal feeders & & $\begin{array}{c}\text { (feeding on pathogenic } \\
\text { fungi) }\end{array}$ & & + \\
\hline Herbivores & $\begin{array}{c}+/-(\text { weed control } / \text { plant } \\
\text { parasitism })\end{array}$ & & + (virus vectors) & + \\
\hline Predators & & + (PPN preying) & & + \\
\hline Omnivorous & & + (PPN preying) & & + \\
\hline Entomopathogens & & + (insect killing) & & + \\
\hline
\end{tabular}

* Signs indicate positive (service) and negative (disservice) contributions (in parenthesis).

Another representation of nematode functional diversity is related to their life history strategies. A combination of traits (e.g., body size, reproductive potential, longevity, tolerance) have been used to classify nematodes along a colonizer-persister (c-p) scale (i.e., classification into $\mathrm{r}$ - and K-selected species), reflecting the habitat quality, maturity and stability [32]. Non-parasitic nematode families were assigned to five classes. These range from r-strategists, having short lifecycle, high reproduction rates, high colonization ability and tolerance to stress (c-p 1), to k-strategists, having long lifecycle, very few offspring, low colonization ability and sensitivity to stress (c-p 5) [33,34]. Based on this classification, the nematode maturity index was developed and extensively tested over three decades. Generally, the c-p ranking is recognized as a functional trait, however it is based on a combination of selected physiological, morphological and behavioral traits. The knowledge on the nematode trophic and life history traits was integrated into a matrix classification of nematode 'guilds' [34]. The soil food web diagnostic framework was then developed, by providing a weighting system for the presence and abundance of nematode "functional guilds" in relation to enrichment and soil food web structure [35].

Nematode communities are mostly surveyed to the genus level and subsequently assigned to feeding and life history groups (at the family level). However, the trophic position and functioning of non-parasitic species continue to be poorly understood, despite their ubiquity and abundance. Moreover, recent studies on Pristionchus spp. showed great polyphenisms (alternative phenotypes produced by the same genotype) in mouth morphology, larval development and reproductive or feeding mode [36-38]. Such a nema- 
tode phenotypic plasticity allows individuals to adapt easily to changing environments, therefore a great functional diversity can be maintained in the absence of substantial genetic variation [39]. With other experimental studies, these observations indicate that the functional role of nematodes may be highly species-specific [40] and that certain functions might involve a complex of multiple species with different specific temporal and spatial cues [41]. An overlap of functional roles is evident in EPN, as these nematodes are both bacterivores and insect parasites.

Although nematodes often represent the dominant eukaryotes in terms of abundance and diversity, most experimental studies used for evaluating their functional role involve a limited number of species. For example, studying the effect of within-trophic level diversity of bacterivorous nematodes and population interactions on nitrogen mineralization, Postma-Blaauw et al. [42] found that the life history strategies of the species of the same trophic group significantly affected their communal impact on the soil ecosystem processes. A single nematode species is able to influence the population size of other species that may, in turn, alter the functioning of the system [43]. How experimental observations can be generalized remains, however, uncertain, in particular if we consider the broad range of ecosystem types and processes globally present. A better approach to adopt would be to investigate these complex systems through long-term field experiments or in situ studies [17].

At first, the functional diversity was assessed mainly as functional group richness (i.e., the number of feeding groups and functional guilds) and their relative abundance. In recent years, the analyses of single or multiple nematode traits were regarded as reliable alternatives to assess the community-level response to disturbances and biodiversityfunctions relationships. In terrestrial ecosystems, the functional trait-based approach has been undertaken for nematode assemblages alone $[44,45]$ or for more complex systems that involve several trophic levels, e.g., bacteria, nematodes and collembolans [46]. Body size, measured either at the individual or species level, has been used to evaluate the interaction strengths between consumers and resources [47], and is correlated directly with properties that influence the performance of organisms and communities [15]. The body size/mass spectra of free-living nematodes as response/effect trait metrics alone or in combination with behavior (feeding structure) and life history strategies have been used to evaluate nematode functional diversity [48-50]. The combination of discrete and continuous traits (trophic groups and body size) distribution rather than the functional diversity indices (functional divergence, functional evenness and functional richness) was found to better reveal the soil food web structure and trait-mediated responses of nematode communities to environmental filters in different ecosystem types [51].

\section{Soil Nematode Communities in Space and Time}

The influence of environmental factors and biotic interactions on biodiversity, community assembly and dynamics in soil is so far unclear. The current meta-community concept postulates that the structure of local communities is shaped by at least three interacting forces: dispersal, environmental filtering and biotic interactions [52]. Being small-bodied organisms, soil nematodes exhibit an aggregate distribution at a microscale level tied to their limited dispersal, niche partitioning and trait plasticity, with plants being one of the key determinants [53]. The soil spatial heterogeneity and the temporal variation in resource availability create high microhabitat diversity, potential for resource utilization and niche partitioning, and hence complex biotic interactions. In natural systems, deterministic (i.e., niche-based) rather than stochastic processes were found to be more important in delimiting the phylogenetic nematode community structure [54]. Closely related nematode phylotypes tended to co-occur more often, demonstrating that closely related lineages occupy similar niches. This provided evidence for the existence of self-organized communities (functional units) that soil supports at a given scale as a result of long periods of coevolution that have selected for the best combination of organisms [55]. 
In contrast to natural and semi-natural systems, the nematode community structure and diversity in agricultural soils are strongly modified by the habitat structure and human activities. These are combined with the ability of local organisms to adapt to greater perturbations and constantly changing factors. Differences in the spatial and temporal availability of major plant resources, i.e., litter and rhizodeposits, separate the nematode fauna into metacommunities [56]. The patterns may also be associated with a complexity of relationships that nematode species have with soil components as a whole, including their own density and that of prey, predators and/or microbial parasites.

Nematode communities also tend to be dynamic, and constantly changing (adapting) over time, as they do in space, as shown by changes in nematode composition and population dynamics, due to endogenous or external drivers. In newly colonized environments, the identification of a "path towards equilibrium" may reveal unexpected external drivers, that contribute to the construction of a stable community. For example, when studying the nematode succession on a pristine volcanic island (Surtsey, Iceland) 50 years after its original formation, Ilieva-Makulec et al. found a progressive increase of nematode taxa over time [57]. However, the presence of seagull colonies on the island increased the diversity and abundance of bacterial and plant-feeding taxa inside the colony area, rich in nutrients and plants, whereas higher numbers of mycophagous species occurred outside, in other less fertile zones. The manner in which soil fertility and vegetation directly and indirectly shape soil communities can vary greatly across organism groups and over the system timescales (chronosequences) [58]. However, the empirical analyses explaining the temporal heterogeneity effects on community assembly and dynamics remain insufficient, calling for more research efforts and investments.

\section{Biodiversity Alterations Due to Agriculture}

\subsection{Land Cover Change}

Deforestation in the tropics is one of the most dramatic contemporary examples which results in a decline in species diversity, including nematode fauna $[59,60]$. Species richness was greater in undisturbed tropical forest than after clearing, cultivation or during regeneration. Re-analyzing the data from south-central Cameroon regarding the effects of tropical forest disturbance and clearance on eight animal groups (birds, butterflies, flying beetles, canopy beetles, canopy ants, leaf-litter ants, termites and soil nematodes), it was found that the effects were stronger on species composition than on richness, and were mostly concordant among taxa [61,62]. In contrast to previous findings [61], species richness for most groups did not decline with disturbance level, thus supporting the view that changes in species richness at local scales do not always reflect the ecosystem response to disturbance. The strength of the relationships between disturbance and community composition relationship depends on the disturbance drivers and the functional groups considered [62]. The greatest observed response was from organisms feeding on plant material (living or dead), including herbivorous nematodes which were, with beetles and termites, the most sensitive to forest disturbance.

Recovery following destruction of vegetation (secondary vegetation) is yet another land process [4] that will result in a marked effect on the after-disturbance nematode communities, although the response appears to be idiosyncratic and case-specific $[63,64]$. The shifts in nematode composition and diversity depend on the initial community structure and appear mediated by plant-soil legacy and the assemblage response to novel conditions. Changes in diversity and trophic structure of nematode communities were studied in relation to both natural and human-driven modifications, e.g., woody plant invasion of grasslands [65], secondary successions after land abandonment [66-68] and ex-arable lands restoration [69]. Using a chronosequence approach to study vegetation shifts from grassland to woodland, Biederman and Boutton [65] found that the taxonomic diversity and overall nematode abundances were unaffected by the development of forest stands in grassland areas. However, the change reduced the evenness component of the taxonomic diversity. Reductions in root-parasitic nematodes ranged from $40 \%$ in grasslands to $<10 \%$ 
in the older wooded areas, while the abundance of bacterivores increased from $30 \%$ of the nematode communities in grasslands to $70-80 \%$ in older woody areas. The effect of spreading hay and soil (independently or combined) and transplanting intact turfs was tested on plant and soil nematode community development, when studying the restoration practices and tools in ex-arable lands [69]. The soil spreading and turf transplantation did not affect the soil nematode community composition at the receptor site, and the introduction of later successional soil organisms into a topsoil-removed site did not facilitate the establishment of later successional plants.

\subsection{Land Use Intensity}

The degree of soil habitat perturbations in agrosytems depends on the type and intensity of the production system (e.g., annual-perennial cropland, conventional-organic management, pasture) and on the previous management (e.g., tillage, rotation regimes, fertilizer application, grazing intensity). Intensive agriculture decreases the abundance/biomass of most groups of soil organisms, and the functional diversity of individual groups of soil biota, altering the community structure and reducing the complexity of the soil food webs [70-72]. Simplification of the soil food webs affects multitrophic interactions, an effect that can significantly impair soil processes, ecosystem functions and services [71,73]. Moreover, land use can strongly affect the resilience of soil food webs and their response to extreme events due to climate changes [74].

Agricultural management practices directly and/or indirectly affect the soil fauna with limited abilities of dispersal and re-colonization, including nematodes. Planting crops (e.g., sugar beet) susceptible to plant parasitic species (e.g., Heterodera schachtii) and long-term intensive cultivation are known to significantly affect nematode diversity by providing a pest selection pressure, modifying the soil structure and increasing chemical pollution [75]. However, not all taxa or functional groups will decrease in density or diversity with increasing crop intensity. Some groups (taxa) are even favored by more intensified cropping practices, such as bacteria, or bacterial and plant feeding nematodes. A general pattern often observed in studies dealing with land use intensification (e.g., increased tillage, fertilizer use and grazing) is the increased role of bacterial- vs. fungalbased food webs [76]. These changes are usually associated with a shift in the proportion of bacterial to fungal feeding nematodes and changes in plant-feeding abundance and taxa composition [77-82]. The nematode operational taxonomic units (OTUs) richness and, to a larger extent, OTUs (and genus) diversity and evenness, and abundance of herbivorous nematodes were higher in reduced compared to conventional tillage, however a soil depth stratification effect of reduced tillage on nematode OTUs and genera, as well as in the relative abundance of trophic groups was found [81]. Nematode communities were more strongly affected by tillage than by organic matter addition.

Another general pattern often observed in disturbed agricultural soils is the lack or decreased abundance of organisms of higher trophic levels, such as carnivorous and omnivorous nematodes [78], assigned to the group of K life strategists (persisters). However, the opposite trend was also occasionally detected $[83,84]$. Studies comparing conventional to no-tillage management showed a greater abundance in no-tillage of nematodes from both trophic groups, while others did not reveal a clear effect on either feeding group $[81,85,86]$. A study on nematicide applications revealed no significant impact on omnivorous and predatory nematode populations, with an observed yearly recovery [83]. The contrasting results could be related to the different response of species (genera) present in the community rather than of the trophic group as a whole. The physical disturbances and chemical/nutrient changes reported likely alter the nematode genera differently, and the indirect effects of management were likely greater than the direct ones [87].

Plant-mediated effects may also cause differences in the nematode response to management practices. Reduced crop diversity in agrosystems, and related reduction in food source variety (e.g., litter quality) with root heterogeneity, decreased nematode diversity, altering the community structure and function, thus decreasing the food web complexity $[79,88,89]$. 
Other studies showed that the nematode abundance was significantly reduced after nematicide applications, especially for plant feeders and predators. When studying different maize crop management systems, monoculture was found to reduce plant and bacterial feeders' diversity [90]. Another study showed that, over five years, complex plant communities developed more complex nematode communities, with a higher ratio of predators to plant feeders and of fungal to bacterial feeding nematodes, thus reducing the relative abundance of plant feeders that were more common in simplified plant communities [91].

Other studies, however, found stronger effects of plant identity rather than diversity on nematode composition [92-94]. Changes in nematode diversity were linked to the presence of a specific crop plant. Plant-soil biota feedbacks can affect the primary productivity in terrestrial habitats and certain ecosystem processes [95-97]. These links are well-known for many parasitic nematodes but are still not well-understood for other herbivorous and free-living species. The plant developmental stage appeared as a dominant determinant of the rhizosphere community, significantly affecting most abundant nematodes [98], and vice versa, by altering competition among plant functional groups, nematodes were found to modify the community structure and functions of semi-natural plant communities [90].

Farming integrating low-impact, system-oriented and sustainable practices is an alternative to the increasing intensification of conventional agriculture. Organic agriculture is a management system with emphasis on the minimal use of off-farm inputs, aiming at restoring, maintaining and enhancing biodiversity, biological cycles and soil biological activity. Different agricultural systems affect nematode communities in diverse ways, which depend on the specific combinations of management practices and environmental factors. These impede the extrapolation of the results from experimental and field studies to other different environmental conditions. Impacts of various practices applied in organic or natural agrosystems on soil biota, including nematode communities, have been extensively studied and compared to conventional agrosystems [99-103]. The effects of various forms of agricultural management on nematode diversity range from negative to positive, depending on the type of practice and the measure of diversity applied [10]. Soil nematode assemblages appear resilient to many management practices. However, the level at which biodiversity is assessed can strongly bias our interpretations. Most analyses are at the generic and trophic levels, but greater changes, or taxon replacement, may occur at the species level [75]. Complementary changes at the taxonomic level may not be detected at the functional diversity level.

\section{Impact in High-Value Crops}

\subsection{Effects of Banana Cropping Systems on Nematodes}

Bananas (Musa spp.) are typically grown in highly commercial, large-scale monoculture plantations. They consist primarily of a single Cavendish genotype and minor variants, while single plantations are usually composed of clones from a single source. This narrow genetic pool represents a major risk for pest and disease outbreaks. Consequently, the banana industry has traditionally relied heavily upon the use of synthetic pesticides to mediate the impact of pests and diseases, including nematodes. As with many tropical crops, bananas are challenged by and susceptible to a range of PPN species. At any one time, they are mostly infected by multiple species [104], which could severely compromise the fruit production and other services provided by plantations.

Most studies on nematode assemblages and functional groups' diversity in banana agrosystems explored the effects of plant cover composition and diversity changes on regulation of the most common PPN [105-109]. The stability and beneficial ecosystem functions and services (e.g., regulation of weeds, pests or pathogens) of intensively managed agrosystems can be enhanced by increasing plant diversity through cover plants or associated crops. Increasing the cover crop species diversity is expected to enhance plant productivity through increased resource use efficiency [110]. Multispecies cropping agrosystems perform multiple functions and services other than crop production, increasing soil $\mathrm{OM}$ and $\mathrm{C}$ sequestration, regulating soil moisture, suppressing weeds, pathogens and pests, retaining 
$\mathrm{N}$, sustaining higher soil biodiversity, etc. Increasing plant richness tends to increase pest regulation in the field. The cover plants may control PPN directly, by various self-defense mechanisms and traits (morphological, physical and chemical) and indirectly-through soil food web modifications, including changes in the relative abundance between PPN and their predators, e.g., carnivorous nematodes or arthropods [111]. The abundance of bacterivorous, omnivorous and root-hair feeding nematodes, and the Shannon-Weaver diversity index, tended to increase when a cover crop was introduced between rows [105]. However, data showed specific effects of cover crop species, as PPN were less abundant in plots with Poaceae than in those with Fabaceae.

Poeydebat et al. [106] investigated the processes leading to PPN regulation in banana agrosystems, evaluating the effects of plant richness (crop and non-crop), soil properties (humidity, soil OM, C:N ratio) and nematode trophic groups on multitrophic interactions. Different pest regulation pathways were found, including regulation of Radopholus similis by plant community effects, of Helicotylenchus multicinctus and Meloidogyne spp. by nontrophic interactions with free-living nematodes and of Pratylenchus coffeae by both effects. No regulation of PPN by predaceous nematodes was found. Other studies showed that previous crop plants, biochemical characteristics of cover crop litter, management type (conventional vs. organic, mixed vs. monoculture) and the type of organic amendments also applied strongly influenced the nematode assemblages, their trophic interactions and complexity, possibly leading to PPN suppression [107-109,112-114].

The PPN biology and host adaptation also play a key role in the damage induced. The burrowing nematode, $R$. similis, is the most important PPN of banana, largely as this tends to be the prominent nematode in commercial dessert banana plantations, where close attention is paid to pest management. However, $R$. similis rarely occurs alone but, as an aggressive species, it often overshadows the presence and damage of other nematode species. Other co-occurring species, such as H. multicinctus and Meloidogyne spp., result in damage beyond that caused by $R$. similis alone [115]. In addition, significant differences in the aggressiveness and damage potential of different populations of $R$. similis have been demonstrated, which are themselves differentially affected by host resistance [116].

Depending on the geographic location, climate and banana genotype, the nematode diversity may differ substantially. In Africa, for instance, $R$. similis has tended to dominate the nematode communities (and damage) in the East African Highland cooking bananas, at altitudes below $1400 \mathrm{~m}$. Above this altitude, Pratylenchus goodeyi, which is more tolerant of cooler temperatures than R. similis, becomes dominant [117-119]. Helicotylenchus multicinctus remains ever present across the altitudinal gradients, while Meloidogyne spp., Rotylenchulus spp., Rotylenchus spp. and other Helicotylenchus spp., among others, regularly occur [103]. In the hotter lowland areas in East Africa, the nematode community composition has shifted away from R. similis, with Pratylenchus coffeae, as well as P. goodeyi, becoming more prevalent [120-122]. In West Africa, however, where $R$. similis has previously been the dominant nematode pest species, a trend in the rise of $P$. coffeae has been observed [117]. Overall, this demonstrates the continuously dynamic nature of PPN on banana and the need to be aware of this dynamism when developing appropriate management options.

The occurrence of multiple damaging species has relevance for management options, especially selective options that may be species-specific, such as host resistance or biological control. Options, therefore, of a more general nature or that combine alternatives with specific target species should be considered in order to effectively manage multiple infections. Previously, in commercial plantations, the regular and repetitive use of the same chemical nematicide was relied upon, but the adaptation of microbes, which quickly degraded them, rendered some treatments ineffective, resulting in the alternate use of different compounds [123]. Chemical nematicide treatments, in addition to fungicides and insecticides, have amounted to extreme levels of application, however, a situation that questions the ecological sustainability of such systems [124,125]. The long-term persistence of some compounds, such as Chlordecone, has also occurred in some instances, leading to their progressive removal from use, and to the search for less hazardous options $[126,127]$. 
In general, the monoculture of banana should be avoided to suppress the build-up of nematode population densities and high, long-term pathogen pressure. In the commercial dessert banana systems, this is not always practical or feasible, while the smallholder systems tend to comprise a tapestry of different cultivars and crops. Although different, both production systems tend to be heavily affected by nematode damage, but for varying reasons. For instance, high pathogen pressures are created in dessert monoculture systems, while infected planting material and a poor understanding of nematode pests perpetuate a nematode infection cycle (and build-up) in smallholder systems. These two very different production systems are also similarly characterized by their associated microbial communities, which contain antagonists capable of suppressing biotic constraints, including PPN [128,129]. Banana plants that appeared to be growing well in otherwise nematode-infested fields were targeted for sampling. Isolation and testing for efficacy against nematodes established a number of microbial candidates that have proved to be effective at managing nematodes and improving banana yields. They have since been employed as biocontrol inoculants, plant strengthening agents and biofertilizers on banana, as well as other crops $[115,130]$.

Banana has a rich microbiome diversity, which is influenced by plant health. In East Africa, banana plants with (symptomatic) and without (asymptomatic) Fusarium wilt were the major drivers of the fungal community composition in the rhizosphere [131]. Isolating specific candidates or mediating the microbial composition towards improving plant vigor or health, or for managing banana pests and diseases, offer much potential and benefits to production.

Nematode pest densities can also be mediated through the use of various intercrops, which have differential host status for nematode pests. Interestingly, preference should be given to intermediate or good R. similis hosts (e.g., common bean and sorgho-Sudangrass), which can result in lower nematode build-up and reduced (long-term) pathogen pressure on the banana crop. Including a poor or non-host crop (e.g., marigold and sunn hemp) can result in an adverse effect on long-term pathogen pressure, as nematodes migrate to banana plants, the good host, aggravating the problem [132]. Conversely, break cropping with non-hosts can be effective where plantations are regularly shifted or replanted. Planting sugarcane (Saccharum hybrid) was found to eliminate R. similis after 10 weeks [133]. Consequently, diversifying the cropping system can have beneficial effects on microbial/nematode diversity, with positive impacts on crop health and productivity. Although Van Asten et al. [134] did not assess the microbiome, they found substantial improvement in productivity and economic benefits in the combined cropping of coffee and banana, compared to either alone.

The mixed and often complex diversity of smallholder cropping conditions may provide multiple benefits that are at first not obvious. For example, banana plants grown in agroforestry systems in Nicaragua and Costa Rica were characterized by greater potential plant-beneficial bacteria, such as Pseudomonas and Stenotrophomonas, while disease-causing species, such as Erwinia, were less represented [135]. Banana plants have also been found to benefit from the presence and colonization by arbuscular mycorrhizal fungi (AMF), which can improve crop production through various mechanisms, including protection against nematodes [136]. AMF inoculants supported more vigorous plantain plants and prevented root invasion by P. coffeae and R. similis in Nigeria [137]. However, the interplay between crops in mixed cropping systems can additionally influence the population levels and diversity of AMF, as well as other microbes. Van der Veken et al. [138] demonstrated that a number of intercrops were more or less compatible to AMF, which could increase or sustain the AMF rhizosphere population. Among them, groundnut and sweet potato are regularly intercropped in banana-based cropping systems in West Africa.

As with most crops, banana similarly responds positively to the practice of mulching. Indeed, banana appears heavily dependent on mulching as an important source of nutrient cycling [139]. However, although organic mulching may facilitate weevil build-up, the benefits tend to outweigh the detrimental aspects, through crop nutrition and the suppression 
of damage caused by nematodes. There are numerous reports available demonstrating the beneficial effect of mulching on nematode damage. However, it is difficult to separate the individual effects of a better nutrition from reduced PPN damage. The rhizosphere microbial diversity will undergo substantial modification following organic mulching, which will depend on the type of OM, the climate, soil type, etc. [140]. The possible negative impact by $P$. goodeyi on banana in Rwanda, for instance, was likely masked by the fact that nematode populations were positively correlated with high plant density and/or mulching practices, which reduced root necrosis and led to relatively high plant vigor, irrespective of soil type [141].

There is no doubt that sturdier banana plants, that have been mulched, become more resilient under nematode attack. This is likely due to multiple reasons, including the modification of the rhizosphere soil microbial community, which becomes richer and more populated with mulching. Studies on plantain in West Africa have consistently demonstrated the improved productivity and longevity of plantations infected with nematodes following mulching, irrespective of the type of mulch [137,142-144], and similarly elsewhere on other banana types $[140,145,146]$. The regular application of relatively small amounts of fresh Tithonia diversifolia leaf material to plantain heavily affected by nematodes in Nigeria demonstrated great beneficial effects on crop performance [147].

\subsection{Diversity and Function of EPN in Banana Crops}

EPN (Rhabditida) have an important role in ecosystem functioning by acting as biological control agents of insect pests [42,148], including relevant pests of banana. They have developed mutualistic-symbiotic relationships with entomopathogenic bacteria, members of $\gamma$-Proteobacteria [148] that are vectored into the hosts, causing their death by septicemia. EPN occur in soils both in natural and agricultural ecosystems in all continents, except Antarctica. Some species from tropical and subtropical regions show potential for practical exploitation in banana crops [149-151].

Although four genera of EPN have been described (Steinernema, Neosteinernema, Heterorhabditis and Oscheius), those with the highest impact in agricultural ecosystems belong to genera Steinernema and Heterorhabditis. Almost all of the EPN lifecycle occurs inside the insect host, and only the third stage, infective juvenile (IJ) (representing a dauer or stress-resistant stage) resides in soil, searching for a new victim and acting as a vector for its associated bacteria [148]. The IJ is also the life-stage that is applied as a biocontrol agent in most commercial formulations based on insect cadavers or as aqueous suspensions in sponges [152-154].

When an insect species is naturally infected, the associated EPN may be considered as a locally adapted population, with a likelihood to act as an effective pest-regulating biocontrol agent. Species from five insect orders (Coleoptera, Hymenoptera, Diptera, Lepidoptera and Orthoptera) have been found naturally infected by EPN [154]. Nevertheless, the majority of EPN species/populations have been isolated from soils, using Galleria mellonella as bait $[149,154]$. EPN epizootics appear uncommon in nature. The patchy EPN distribution [155] and persistence in soil depend on biotic and abiotic factors such as the presence of hosts, or organisms such as mites, collembolas and fungi, that could predate on the EPN populations, the soil type ( $\mathrm{pH}$, texture, clay/sand percentage, moisture), geographic regions, altitude, vegetation (specie/cultivars) and agricultural practices [156].

EPN play several roles in soil ecosystems. Beside their function as insect regulators, they are natural components of the soil food webs. When they are applied as augmentative biological control agents, they are integrated as a natural component to the soil food web [157]. The relationship between EPN and other trophic guild nematodes in soil involves competition for resource exploitation, observed between indigenous free-living bacterivorous nematodes and EPN [158]. In Florida, EPNs and members of the Acrobeloides-group were detected in all sites sampled, and the abundances of the two guilds were positively related [159]. The correlation between prevalence of $S$. riobrave and free-living bacterivorous 
nematodes revealed the possibility that application of EPN induced a population growth of bacterivorous species [160].

The presence and persistence of EPN populations has also been related to land use change and degradation. It is known that modifications in the above-ground area also produce changes in the rhizosphere, as intensification of land use often negatively affects the occurrence and recovery of EPN. Several studies showed that EPN occurrence is lower in agricultural soils, i.e., annual cropland or pastures, than in natural and secondary forests [161,162]. Other studies, however showed that EPN abundance and frequency were higher in annual crops than in natural areas [163]. In conventional agricultural lands, some practices may affect the presence, survival and infectivity of different EPN species/populations. They include tillage and intensive use of pesticides [164]. According to Barker and Barker [165], organisms in the higher trophic levels of soil, such as EPN, may be sensitive to environmentally induced, bottom-up cascade effects that alter the availability of hosts.

The EPN efficacy as biocontrol agents of several above- or below-ground insect pests and production conditions (pastures, orchards, greenhouses, or others) encouraged several companies to produce EPN in vivo or in vitro, formulated using many species or populations [166,167]. Several insect pests affect Musa-growing areas, with Cosmopolites sordidus (banana weevil, BW) as the main and specific rhizome pest. Its larvae feed and produce galleries, whereas the adults emerge from the rhizome and move in soil around the pseudostem [168]. This type of insect habit represents a severe challenge for efficient control, due to the vast network of feeding galleries produced. Excellent control of BW was obtained by applying EPN in moist and cryptic habitats, considered as alternative methods [169-171]. Several EPN species/populations were evaluated in laboratory and field assays for BW management and other pests, such as the banana moth Opogona sacchari (bunch pest in the Canary Islands and Brazil) and Metamasius spp., minor or sporadic banana pests in America [169-173]. EPN diversity is an important resource in BW bio-management, but few studies have been conducted on the variability of local EPN populations. Local and foreign species/populations of Steinernema and Heterorhabditis were evaluated in different conditions, causing variable mortalities in larvae and adults of BW and other pests as well. Several Steinernema and Heterorhabditis spp. have been tested in tropical and subtropical areas [171-184]. Many species/populations were recovered in several tropical countries, when prospecting for EPN, both in Musa spp. monocrops or mixed with others species [176-194].

In agricultural areas with more frequent organic or agroecological management, EPN adapted to local conditions are more abundant and persistent, compared with more intensive farmed habitats [195]. Several studies indicated that practices, such as conservation tillage, use of mulching or application of crop residues over soil surface, do not affect EPN persistence and activity. Meanwhile, other factors affect EPN, i.e., the use of sugarcane filter mud as manure in clay soils, reinforcing the pertinence of studies on EPN populations under different environmental conditions and agricultural technologies [195-199].

\subsection{Nematodes in Apple Crops}

Apple (Malus domestica) crops are produced in all temperate and subtropical regions of the world and represent the fourth most important fruit crop after citrus, grapes and banana [200]. EUROSTAT data indicated this crop as the most commonly planted fruit tree in the European Union (EU), with a cultivated area covering 473,500 ha or $37 \%$ of the land covered by orchards in 2017. Similar to other agrosystems, apple production systems can provide numerous services or disservices that depend on locality, management type and applied practices [201,202]. In addition, apple orchards contribute to services, such as pollination, pest control, soil fertility, nutrient cycling and soil biodiversity conservation in more environment-friendly production systems, when either organic management or novel biodiversity-enhancing practices are used [202-204]. The trade-offs between provisioning 
and other ecosystem services and disservices usually arise from the management choices and should be evaluated in terms of the spatial and temporal scales [205].

Most nematode studies in apple orchards have focused on PPN. However, several recent studies investigated nematode community structure in relation to crop management type or soil management practices [103,206-209]. A more comprehensive approach including other soil organisms, such as protozoa [208], AMF [209] and soil microbes and microfauna (e.g., fungi, bacteria, algae and protozoa), has been used [207] for studying soil management practices. DNA-based methods were applied too $[102,210]$. The community structure and diversity of bacteria, fungi and nematodes, and their relationships from naturally and conventionally farmed apple orchards, were studied in Japan using denaturing gradient gel electrophoresis (DGGE) [102]. The results indicate that crop type as well as management practices improved the nematode community structure and functional diversity in organic and natural apple orchards, as compared to conventional apple production. However, data relating these results to fruit production and quality were not shown.

Studying the functional diversity of nematodes and their relationship with other organisms of the soil food web may help to reveal their contribution to ecosystem services and disservices provided by apple orchards (e.g., pest/disease control vs. apple replant disease, ARD). ARD is common to all major apple growing regions worldwide [211]. It affects plant propagation in nurseries and replanted apple orchards reducing plant growth, as well as fruit yield and quality [212]. Studies on the ARD etiology and soil biology in apple orchards have defined a complex of soil-borne pathogens and parasites as causal agents. In particular, some fungi (Fusarium and Rhizoctonia), oomycetes (Phytophthora and Pythium) and nematodes (Pratylenchus spp.) have been identified as key causal agents [213]. Previous research on ARD focused on PPN, mainly Pratylenchus penetrans [214], while the role of free-living nematodes in the disease complex was neglected. However, a recent study proved the importance of free-living nematodes and their synergetic role to induce ARD [210]. The authors explored the source of the inoculated nematodes (ARD or control soil) and the interaction between ARD nematodes and microbes as factors determining the disease insurgence. They found that when nematode communities extracted from the ARD soil were added to microbes, regardless of their origin, they affected plant growth more severely than treatments without ARD nematodes. The nematodes extracted from control soil in combination with microbes, either from ARD or control soil, did not induce ARD symptoms. The outcomes underline the indirect role of free-living nematodes in transmitting pathogenic microbiota.

\section{Concluding Remarks}

Although our knowledge on the ecology of terrestrial nematodes has greatly improved over the last few decades, our understanding on the effect of nematode diversity on specific soil functions and ecosystem processes remains insufficient. This can be attributed to difficulties in identifying and functionally classifying the great diversity of taxa in field studies and to the challenges encountered in assembling manageable and well-defined multispecies model systems, when studying the role of nematodes in soil and ecosystem processes. As part of the immense soil biodiversity, nematodes are involved in complex ecological networks, having various interactions with other soil organisms, therefore the ecosystem approach and DNA-based techniques should be embraced when future studies are designed.

Land-use conversion and land-use intensity are the two major impacts related to agriculture that significantly affect soil biodiversity, food web structure and complexity, causing shifts in below-ground communities, including nematode fauna. Intensively managed agrosystems, characterized by higher levels of disturbance and lower plant diversity, are more vulnerable to the detrimental effects of soil-borne pathogens and pests, which compromise their functioning and services. Frequent perturbations in intensively managed land may select for genera with particular life history traits, such as r-strategists with high reproduction rates and small body size, and plant parasitic species, thus creating simplified 
networks and disturbed relationships. Permanent crops, such as banana and apple production systems, provide a rich platform to study both the nematode pests and beneficial species in relation to the soil microbiome. The diverse and ever-evolving complexity of nematode communities demands the development of dynamic management practices that account for nematode functional diversity and multi-species interactions. Understanding the soil microbiome and microfauna diversity and composition in banana/apple cropping systems, and harnessing the related beneficial interactions, can provide a significant and positive impact on the environment. Enhancing research on nematode functional diversity and links with above- and below-ground biota is an important step toward understanding soil ecosystems' processes and services. Coordinated, interdisciplinary and long-term studies on soil biodiversity-ecosystem function relationships may provide comprehensive empirical data needed to develop multi-component models [17]. Results will provide knowledge for the development of management and restoration activities, by manipulating above- and below-ground associations-a major challenge in future agroecology [215].

Author Contributions: Conceptualization, S.L. and A.C.; writing-original draft preparation, all authors; writing - review and editing, all authors; project administration and funding acquisition, A.C. All authors have read and agreed to the published version of the manuscript.

Funding: This research was partially funded by the EU H2020 Programme, Grant Agreement number 727624 "MUSA", by ANIDIV-4 project, Bulgarian Academy of Sciences, and by COST Action FP1305 “BioLink”.

Acknowledgments: We gratefully acknowledge Raquel Campos-Herrera for the revision and suggestions provided on EPN and to both reviewers for their constructive comments and feedback on the manuscript.

Conflicts of Interest: The authors declare no conflict of interest.

\section{References}

1. IPBES. The IPBES assessment report on land degradation and restoration. In Secretariat of the Intergovernmental Science-Policy Platform on Biodiversity and Ecosystem Services; Montanarella, L., Scholes, R., Brainich, A., Eds.; FRD: Bonn, Germany, 2018; 744p.

2. World Resources Institute. Millennium Ecosystem Assessment: Ecosystems and Human Well-Being: Biodiversity Synthesis; Island Press: Washington, DC, USA, 2005; 137p.

3. Ellis, E.C.; Ramankutty, N. Putting people in the map: Anthropogenic biomes of the world. Front. Ecol. Environ. 2008, 6, 439-447. [CrossRef]

4. Knapp, S.; Schweiger, O.; Kraberg, A.; Asmus, H.; Asmus, R.; Brey, T.; Frickenhaus, S.; Gutt, J.; Kühn, I.; Liess, M.; et al. Do drivers of biodiversity change differ in importance across marine and terrestrial systems-Or is it just different research communities' perspectives? Sci. Total Environ. 2017, 574, 191-203. [CrossRef] [PubMed]

5. Newbold, T.; Hudson, L.N.; Hill, S.L.; Contu, S.; Lysenko, I.; Senior, R.A.; Börger, L.; Bennett, D.J.; Choimes, A.; Collen, B.; et al. Global effects of land use on local terrestrial biodiversity. Nature 2015, 520, 45-50. [CrossRef] [PubMed]

6. Bardgett, R.D.; Wardle, D.A. Aboveground-Belowground Linkages: Biotic Interactions, Ecosystem Processes, and Global Change; Oxford University Press: Oxford, UK, 2010; 301p. [CrossRef]

7. Emmerson, M.; Morales, M.B.; Oñate, J.J.; Batary, P.; Berendse, F.; Liira, J.; Aavik, T.; Guerrero, I.; Bommarco, R.; Eggers, S.; et al. How agricultural intensification affects biodiversity and ecosystem services. In Large-Scale Ecology: Model Systems to Global Perspectives; Advances in Ecological Research; Dumbrell, A.J., Kordas, R.L., Woodward, G., Eds.; Academic Press: Cambridge, MA, USA, 2016; Volume 55, pp. 43-97. [CrossRef]

8. Veresoglou, S.D.; Halley, J.M.; Rillig, M.C. Extinction risk of soil biota. Nat. Commun. 2015, 6, 8862. [CrossRef] [PubMed]

9. Porazinska, D.L.; Giblin-Davis, R.; Faller, L.; Farmerie, W.; Kanzaki, N.; Morris, K.; Powers, T.O.; Tucker, A.E.; Sung, W.; Thomas, K.W. Evaluating high-throughput sequencing as a method for metagenomic analysis of nematode diversity. Mol. Ecol. Res. 2009, 9, 1439-1450. [CrossRef]

10. Hodda, M.; Peters, L.; Traunspurger, W. Nematode diversity in terrestrial, freshwater aquatic and marine systems. In Nematodes as Environmental Indicators; CABI Publishing: Wallingford, UK, 2009; pp. 45-94. [CrossRef]

11. Yeates, G.W.; Ferris, H.; Moens, T.; Van der Putten, W.H. The role of nematodes in ecosystems. In Nematodes as Environmental Bioindicators; Wilson, M.J., Kakouli-Duarte, T., Eds.; CABI Publishing: Wallingford, UK, 2009; pp. 1-44. [CrossRef]

12. Neher, D.A. Ecology of plant and free-living nematodes in natural and agricultural soil. Annu. Rev. Phytopathol. 2010, 48, 371-394. [CrossRef]

13. Ferris, H.; Griffiths, B.S.; Porazinska, D.L.; Powers, T.O.; Wang, K.H.; Tenuta, M. Reflections on plant and soil nematode ecology: Past, present and future. J. Nematol. 2012, 44, 115-126. 
14. Hooper, D.U.; Chapin, F.S.; Ewel, J.J.; Hector, A.; Inchausti, P.; Lavorel, S.; Lawton, J.H.; Lodge, D.M.; Loreau, M.; Naeem, S.; et al. Effects of biodiversity on ecosystem functioning: A consensus of current knowledge. Ecol. Mon. 2005, 75, 3-5. [CrossRef]

15. McGill, B.J.; Enquist, B.J.; Weiher, E.; Westoby, M. Rebuilding community ecology from functional traits. Trends Ecol. Evol. 2006, 21, 178-185. [CrossRef]

16. Tilman, D. Functional diversity. In Encyclopaedia of Biodiversity; Levin, S.A., Ed.; Academic Press: San Diego, CA, USA, 2001; pp. 109-120. [CrossRef]

17. Weisser, W.W.; Roscher, C.; Meyer, S.T.; Ebeling, A.; Luo, G.; Allan, E.; Beßler, H.; Barnard, R.L.; Buchmann, N.; Buscot, F.; et al. Biodiversity effects on ecosystem functioning in a 15-year grassland experiment: Patterns, mechanisms, and open questions. Basic Appl. Ecol. 2017, 23, 1-73. [CrossRef]

18. Gagic, V.; Bartomeus, I.; Jonsson, T.; Taylor, A.; Winqvist, C.; Fischer, C.; Slade, E.M.; Steffan-Dewenter, I.; Emmerson, M.; Potts, S.G.; et al. Functional identity and diversity of animals predict ecosystem functioning better than species-based indices. Proc. $R$. Soc. Lond. B Biol. Sci. 2015, 282, 2014-2620. [CrossRef]

19. Gross, N.; Bagousse-Pinguet, Y.; Liancourt, P.; Berdugo, M.; Gotelli, N.J.; Maestre, F.T. Functional trait diversity maximizes ecosystem multifunctionality. Nat. Ecol. Evol. 2017, 1, 132. [CrossRef]

20. Manning, P.; van der Plas, F.; Soliveres, S.; Allan, E.; Maestre, F.T.; Mace, G.; Whittingham, M.J.; Fischer, M. Redefining ecosystem multifunctionality. Nat. Ecol. Evol. 2018, 2, 427-436. [CrossRef] [PubMed]

21. Delgado-Baquerizo, M.; Reich, P.B.; Trivedi, C.; Eldridge, D.J.; Abades, S.; Alfaro, F.D.; Bastida, F.; Berhe, A.A.; Cutler, N.A.; Gallardo, A.; et al. Multiple elements of soil biodiversity drive ecosystem functions across biomes. Nat. Ecol. Evol. 2020, 4, 210-220. [CrossRef]

22. Mouillot, D.; Graham, N.A.; Villéger, S.; Mason, N.W.; Bellwood, D.R. A functional approach reveals community responses to disturbances. Trends Ecol. Evol. 2013, 28, 167-177. [CrossRef] [PubMed]

23. Brussaard, L. Ecosystem services provided by the soil biota. In Soil Ecology and Ecosystem Services; Wall, D., Bardgett, R.D., Behan-Pelletier, V., Herrick, J.E., Hefin Jones, T., Ritz, K., Six, J., Strong, D.R., van der Putten, W.H., Eds.; Oxford University Press: Oxford, UK, 2012; pp. 45-58. [CrossRef]

24. Wright, J.P.; Naeem, S.; Hector, A.; Lehman, C.; Reich, P.B.; Schmid, B.; Tilman, D. Conventional functional classification schemes underestimate the relationship with ecosystem functioning. Ecol. Lett. 2006, 9, 111-120. [CrossRef] [PubMed]

25. Violle, C.; Navas, M.L.; Vile, D.; Kazakou, E.; Fortunel, C.; Hummel, I.; Garnier, E. Let the concept of trait be functional! Oikos 2007, 116, 882-892. [CrossRef]

26. Nock, C.A.; Vogt, R.J.; Beisner, B.E. Functional Traits. In eLS; John Wiley \& Sons, Ltd.: Chichester, UK, 2016; pp. 1-8. [CrossRef]

27. Campos-Herrera, R. Nematodes Pathogenesis of Insect and Other Pest: Ecology and Applied Technologies for Sustainable Plant and Crop Protection; Springer: Cham, Switzerland; Heidelberg, Germany; New York, NY, USA; Dordrecht, The Netherlands; London, UK, 2015; pp. 285-508.

28. Ferris, H. Contribution of nematodes to the structure and function of the soil food web. J. Nematol. 2010, 42, 63-67.

29. Ekschmitt, K.; Bakonyi, G.; Bongers, M.; Bongers, T.; Boström, S.; Dogan, H.; Harrison, A.; Kallimanis, A.; Nagy, P.; O’Donnell, A.G.; et al. Effects of the nematofauna on microbial energy and matter transformation rates in European grassland soils. Plant Soil 1999, 212, 45-61. [CrossRef]

30. Bonkowski, M.; Villenave, C.; Griffiths, B. Rhizosphere fauna: The functional and structural diversity of intimate interactions of soil fauna with plant roots. Plant Soil 2009, 321, 213-233. [CrossRef]

31. Knox, O.G.; Killham, K.; Mullins, C.E.; Wilson, M.J. Nematode-enhanced microbial colonization of the wheat rhizosphere. FEMS Microbiol. Lett. 2003, 225, 227-233. [CrossRef]

32. Bongers, T. The maturity index, the evolution of nematode life history traits, adaptive radiation and cp-scaling. Plant Soil 1999, 212, 13-22. [CrossRef]

33. Bongers, T. The maturity index: An ecological measure of environmental disturbance based on nematode species composition. Oecologia 1990, 83, 14-19. [CrossRef]

34. Bongers, T.; Bongers, M. Functional diversity of nematodes. Appl. Soil Ecol. 1998, 10, 239-251. [CrossRef]

35. Ferris, H.; Bongers, T.; de Goede, R.G.M. A framework for soil food web diagnostics: Extension of the nematode faunal analysis concept. Appl. Soil Ecol. 2001, 18, 13-29. [CrossRef]

36. Sommer, R.J.; Dardiry, M.; Lenuzzi, M.; Namdeo, S.; Renahan, T.; Sieriebriennikov, B.; Werner, M.S. The genetics of phenotypic plasticity in nematode feeding structures. Open Biol. 2017, 7, 160332. [CrossRef]

37. Susoy, V.; Herrmann, M.; Kanzaki, N.; Kruger, M.; Nguyen, C.N.; Rödelsperger, C.; Röseler, W.; Weiler, C.; Giblin-Davis, R.M.; Ragsdale, E.J.; et al. Large-scale diversification without genetic isolation in nematode symbionts of figs. Sci. Adv. 2016, 2, e1501031. [CrossRef] [PubMed]

38. Sanghvi, G.V.; Baskaran, P.; Röseler, W.; Sieriebriennikov, B.; Rödelsperger, C.; Sommer, R.J. Life history responses and gene expression profiles of the nematode Pristionchus pacificus cultured on Cryptococcus yeasts. PLoS ONE 2016, 11, e0164881. [CrossRef]

39. Phillips, P.C. Evolution: Five heads are better than one. Curr. Biol. 2016, 26, R283-R285. [CrossRef]

40. De Mesel, I.; Derycke, S.; Swings, J.; Vincx, M.; Moens, T. Role of nematodes in decomposition processes: Does within-trophic group diversity matter? Mar. Ecol. Prog. Ser. 2006, 321, 157-166. [CrossRef]

41. Sylvain, Z.A.; Wall, D.H. Linking soil biodiversity and vegetation: Implications for a changing planet. Am. J. Bot. 2011, 98, 517-527. [CrossRef] [PubMed] 
42. Postma-Blaauw, M.B.; de Vries, F.T.; de Goede, R.G.M.; Bloem, J.; Faber, J.H.; Brussaard, L. Within-trophic group interactions of bacterivorous nematode species and their effects on the bacterial community and nitrogen mineralization. Oecologia 2005, 142, 428-439. [CrossRef]

43. Trap, J.; Bonkowski, M.; Plassard, C.; Villenave, C.; Blanchart, E. Ecological importance of soil bacterivores for ecosystem functions. Plant Soil 2016, 398, 1-24. [CrossRef]

44. Vonk, J.A.; Breure, A.M.; Mulder, C. Environmentally-driven dissimilarity of trait-based indices of nematodes under different agricultural management and soil types. Agric. Ecosyst. Environ. 2013, 179, 133-138. [CrossRef]

45. George, P.B.; Lindo, Z. Application of body size spectra to nematode trait-index analyses. Soil Biol. Biochem. 2015, 84, 15-20. [CrossRef]

46. Sechi, V.; De Goede, R.G.M.; Rutgers, M.; Brusaard, L.; Mulder, C.A. Community trait-based approach to ecosystem functioning in soil. Agric. Ecosyst. Environ. 2017, 239, 265-273. [CrossRef]

47. Mulder, C.; Boit, A.; Mori, S.; Vonk, J.A.; Dyer, S.D.; Faggiano, L.; Geisen, S.; Gonzalez, A.L.; Kaspari, M.; Lavorel, S.; et al. Distributional (in)congruence of biodiversity-Ecosystem functioning. In Advances in Ecological Research: Global Change in Multispecies Systems, Part 1; Ute, J., Woodward, G., Eds.; Academic Press: Cambridge, MA, USA, 2012; pp. 1-88. [CrossRef]

48. Mulder, C.; Vonk, J.A. Nematode traits and environmental constraints in 200 soil systems: Scaling within the $60-6000 \mu \mathrm{m}$ body size range. Ecology 2011, 92, 2004. [CrossRef]

49. Turnbull, M.S.; George, P.B.; Lindo, Z. Weighing in: Size spectra as a standard tool in soil community analyses. Soil Biol. Biochem. 2014, 68, 366-372. [CrossRef]

50. Liu, T.; Guo, R.; Wei, R.; Whalen, J.K.; Li, H. Body size is a sensitive trait-based indicator of soil nematode community response to fertilization in rice and wheat agroecosystems. Soil Biol. Biochem. 2015, 88, 275-281. [CrossRef]

51. Sechi, V.; De Goede, R.G.; Rutgers, M.; Brussaard, L.; Mulder, C. Functional diversity in nematode communities across terrestrial ecosystems. Basic Appl. Ecol. 2018, 30, 76-86. [CrossRef]

52. Leibold, M.A.; Holyoak, M.; Mouquet, N.; Amarasekare, P.; Chase, J.M.; Hoopes, M.F.; Holt, R.D.; Shurin, J.B.; Law, R.; Tilman, D.; et al. The metacommunity concept: A framework for multi-scale community ecology. Ecol. Lett. 2004, 7, 601-613. [CrossRef]

53. Ettema, C.H.; Wardle, D.A. Spatial soil ecology. Trends Ecol. Evol. 2002, 17, 177-183. [CrossRef]

54. Moroenyane, I.; Dong, K.; Singh, D.; Chimphango, S.B.; Adams, J.M. Deterministic processes dominate nematode community structure in the Fynbos Mediterranean heathland of South Africa. Evol. Ecol. 2016, 30, 685-701. [CrossRef]

55. Lavelle, P. Soil as a habitat. In Soil Ecology and Ecosystem Services; Wall, D., Bardgett, R.D., Behan-Pelletier, V., Herrick, J.E., Hefin Jones, T., Ritz, K., Six, J., Strong, D.R., van der Putten, W.H., Eds.; Oxford University Press: Oxford, UK, $2012 ;$ pp. 7-27.

56. Scharroba, A.; Dibbern, D.; Hünninghaus, M.; Kramer, S.; Moll, J.; Butenschoen, O.; Bonkowski, M.; Buscot, F.; Kandeler, E.; Koller, R.; et al. Effects of resource availability and quality on the structure of the micro-food web of an arable soil across depth. Soil Biol. Biochem. 2012, 50, 1-11. [CrossRef]

57. Ilieva-Makulec, K.; Bjarnadottir, B.; Sigurdsson, B.D. Nematode diversity, abundance and community structure 50 years after the formation of the volcanic island of Surtsey. Biogeosci. Discuss 2014, 11, 14239-14267. [CrossRef]

58. Bokhorst, S.; Kardol, P.; Bellingham, P.J.; Kooyman, R.M.; Richardson, S.J.; Schmidt, S.; Wardle, D.A. Responses of communities of soil organisms and plants to soil aging at two contrasting long-term chronosequences. Soil Biol. Biochem. 2017, 106, 69-79. [CrossRef]

59. Bloemers, G.F.; Hodda, M.; Lambshead, P.J.; Lawton, J.H.; Wanless, F.R. The effects of forest disturbance on diversity of tropical soil nematodes. Oecologia 1997, 111, 575-582. [CrossRef]

60. De Castro Solar, R.R.; Barlow, J.; Andersen, A.N.; Schoereder, J.H.; Berenguer, E.; Ferreira, J.N.; Gardner, T.A. Biodiversity consequences of land-use change and forest disturbance in the Amazon: A multi-scale assessment using ant communities. Biol. Cons. 2016, 197, 98-107. [CrossRef]

61. Lawton, J.H.; Bignell, D.E.; Bolton, B.; Bloemers, G.F.; Eggleton, P.; Hammond, P.M.; Hodda, M.; Holt, R.D.; Larsen, T.B.; Mawdsley, N.A.; et al. Biodiversity inventories, indicator taxa and effects of habitat modification in tropical forest. Nature 1998, 391, 72-76. [CrossRef]

62. Stork, N.E.; Srivastava, D.S.; Eggleton, P.; Hodda, M.; Lawson, G.; Leakey, R.R.; Watt, A.D. Consistency of effects of tropical-forest disturbance on species composition and richness relative to use of indicator taxa. Cons. Biol. 2017, 31, 924-933. [CrossRef]

63. Todd, T.C.; Powers, T.O.; Mullin, P.G. Sentinel nematodes of land-use change and restoration in tallgrass prairie. J. Nematol. 2006, $38,20-27$.

64. Li, Y.; Feng, J.; Chen, J.; Wu, J. Original vegetation type affects soil nematode communities. Appl. Soil Ecol. 2007, 35, 68-78. [CrossRef]

65. Biederman, L.A.; Boutton, T.W. Biodiversity and trophic structure of soil nematode communities are altered following woody plant invasion of grassland. Soil Biol. Biochem. 2009, 41, 1943-1950. [CrossRef]

66. Kardol, P.; Bezemer, T.M.; Van der Wal, A.; Van der Putten, W.H. Successional trajectories of soil nematode and plant communities in a chronosequence of ex-arable lands. Biol. Cons. 2005, 126, 317-327. [CrossRef]

67. Holtkamp, R.; Kardol, P.; Van der Wal, A.; Dekker, S.C.; Van der Putten, W.H.; de Ruiter, P.C. Soil food web structure during ecosystem development after land abandonment. Appl. Soil Ecol. 2008, 39, 23-34. [CrossRef]

68. Kardol, P.; Newton, J.S.; Bezemer, T.M.; Maraun, M.; Van der Putten, W.H. Contrasting diversity patterns of soil mites and nematodes in secondary succession. Acta Oecol. 2009, 35, 603-609. [CrossRef] 
69. Kardol, P.; Bezemer, T.M.; Van Der Putten, W.H. Soil organism and plant introductions in restoration of species-rich grassland communities. Rest. Ecol. 2009, 17, 258-269. [CrossRef]

70. Postma-Blaauw, M.B.; De Goede, R.G.; Bloem, J.; Faber, J.H.; Brussaard, L. Soil biota community structure and abundance under agricultural intensification and extensification. Ecology 2010, 91, 460-473. [CrossRef]

71. Wagg, C.; Bender, S.F.; Widmer, F.; Van der Heijden, M.G.A. Soil biodiversity and soil community composition determine ecosystem multifunctionality. Proc. Natl. Acad. Sci. USA 2014, 111, 5266-5270. [CrossRef] [PubMed]

72. Tsiafouli, M.A.; Thébault, E.; Sgardelis, S.P.; Ruiter, P.C.; Putten, W.H.; Birkhofer, K.; Hemerik, L.; Vries, F.T.; Bardgett, R.D.; Brady, M.V.; et al. Intensive agriculture reduces soil biodiversity across Europe. Glob. Chang. Biol. 2015, 21, 973-985. [CrossRef]

73. De Vries, F.T.; Thébault, E.; Liiri, M.; Birkhofer, K.; Tsiafouli, M.A.; Bjørnlund, L.; Jørgensen, H.B.; Brady, M.V.; Christensen, S.; de Ruiter, P.C.; et al. Soil food web properties explain ecosystem services across European land use systems. Proc. Natl. Acad. Sci. USA 2013, 110, 14296-14301. [CrossRef]

74. De Vries, F.T.; Liiri, M.E.; Bjørnlund, L.; Bowker, M.A.; Christensen, S.; Setälä, H.M.; Bardgett, R.D. Land use alters the resistance and resilience of soil food webs to drought. Nat. Clim. Chang. 2012, 2, 276-280. [CrossRef]

75. Yeates, G.W. Diversity of nematodes. In Biodiversity in Agricultural Production Systems; Benckiser, G., Schnell, S., Eds.; Taylor \& Francis/CRC Press: Boca Raton, FL, USA, 2006; pp. 215-236. [CrossRef]

76. Hendrix, P.F.; Parmelee, R.W.; Crossley, D.A.; Coleman, D.C.; Odum, E.P.; Groffman, P.M. Detritus food webs in conventional and no-tillage agroecosystems. BioScience 1986, 36, 374-380. [CrossRef]

77. Parfitt, R.L.; Yeates, G.W.; Ross, D.J.; Schon, N.L.; Mackay, A.D.; Wardle, D.A. Effect of fertilizer, herbicide and grazing management of pastures on plant and soil communities. Appl. Soil Ecol. 2010, 45, 175-186. [CrossRef]

78. Hu, J.; Wu, J.; Ma, M.; Nielsen, U.N.; Wang, J.; Du, G. Nematode communities response to long-term grazing disturbance on Tibetan plateau. Eur. J. Soil Biol. 2015, 69, 24-32. [CrossRef]

79. Sánchez-Moreno, S.; Castro, J.; Alonso-Prados, E.; Alonso-Prados, J.L.; García-Baudín, J.M.; Talavera, M.; Durán-Zuazo, V.H. Tillage and herbicide decrease soil biodiversity in olive orchards. Agron. Sustain. Dev. 2015, 35, 691-700. [CrossRef]

80. Brmež, M.; Ivezić, M.; Raspudić, E. Effect of mechanical disturbances on nematode communities in arable land. Helminthologia 2006, 43, 117-121. [CrossRef]

81. Bongiorno, G.; Bodenhausen, N.; Bünemann, E.K.; Brussaard, L.; Geisen, S.; Mäder, P.; Quist, C.W.; Walser, J.C.; De Goede, R.G. Reduced tillage, but not organic matter input, increased nematode diversity and food web stability in European long-term field experiments. Mol. Ecol. 2019, 28, 4987-5005. [CrossRef] [PubMed]

82. Sauvadet, M.; Chauvat, M.; Cluzeau, D.; Maron, P.A.; Villenave, C.; Bertrand, I. The dynamics of soil micro-food web structure and functions vary according to litter quality. Soil Biol. Biochem. 2016, 95, 262-274. [CrossRef]

83. Timper, P.; Davis, R.; Jagdale, G.; Herbert, J. Resiliency of a nematode community and suppressive service to tillage and nematicide application. Appl. Soil Ecol. 2012, 59, 48-59. [CrossRef]

84. Roth, E.; Samara, N.; Ackermann, M.; Seiml-Buchinger, R.; Saleh, A.; Ruess, L. Fertilization and irrigation practice as source of microorganisms and the impact on nematodes as their potential vectors. Appl. Soil Ecol. 2015, 90, 68-77. [CrossRef]

85. Okada, H.; Harada, H. Effects of tillage and fertilizer on nematode communities in a Japanese soybean field. Appl. Soil Ecol. 2007, 35, 582-598. [CrossRef]

86. Wang, K.H.; McSorley, R.; Gallaher, R.N. Relationship of soil management history and nutrient status to nematode community structure. Nematropica 2004, 34, 83-95.

87. Fiscus, D.A.; Neher, D.A. Distinguishing sensitivity of free-living soil nematode genera to physical and chemical disturbances. Ecol. Appl. 2002, 12, 565-575. [CrossRef]

88. Santiago, D.C.; de Oliveira Arieira, G.; De Almeida, E.; de Fátima Guimarães, M. Responses of soil nematode communities to agroecological crop management systems. Nematology 2012, 14, 209-221. [CrossRef]

89. Sauvadet, M.; Chauvat, M.; Fanin, N.; Coulibaly, S.; Bertrand, I. Comparing the effects of litter quantity and quality on soil biota structure and functioning: Application to a cultivated soil in Northern France. Appl. Soil Ecol. 2016, 107, 261-271. [CrossRef]

90. Eisenhauer, N.; Ackermann, M.; Gass, S.; Klier, M.; Migunova, V.; Nitschke, N.; Ruess, L.; Sabais, A.C.; Weisser, W.W.; Scheu, S. Nematicide impacts on nematodes and feedbacks on plant productivity in a plant diversity gradient. Acta Oecol. 2010, 36, 477-483. [CrossRef]

91. Eisenhauer, N.; Migunova, V.D.; Ackermann, M.; Ruess, L.; Scheu, S. Changes in plant species richness induce functional shifts in soil nematode communities in experimental grassland. PLoS ONE 2011, 6, e24087. [CrossRef] [PubMed]

92. De Deyn, G.B.; Raaijmakers, C.E.; Van Ruijven, J.; Berendse, F.; Van Der Putten, W.H. Plant species identity and diversity effects on different trophic levels of nematodes in the soil food web. Oikos 2004, 106, 576-586. [CrossRef]

93. Bezemer, T.M.; Fountain, M.T.; Barea, J.M.; Christensen, S.; Dekker, S.C.; Duyts, H.; Van Hal, R.; Harvey, J.A.; Hedlund, K.; Maraun, M.; et al. Divergent composition but similar function of soil food webs of individual plants: Plant species and community effects. Ecology 2010, 91, 3027-3036. [CrossRef]

94. Scharroba, A.; Kramer, S.; Kandeler, E.; Ruess, L. Spatial and temporal variation of resource allocation in an arable soil drives community structure and biomass of nematodes and their role in the micro-food web. Pedobiology 2016, 59, 111-120. [CrossRef]

95. Wardle, D.A.; Bardgett, R.D.; Klironomos, J.N.; Setälä, H.; van der Putten, W.H.; Wall, D.H. Ecological linkages between aboveground and belowground biota. Science 2004, 304, 1629-1633. [CrossRef] [PubMed] 
96. Putten, W.H.; Bradford, M.A.; Pernilla Brinkman, E.; Voorde, T.F.; Veen, G.F. Where, when and how plant-soil feedback matters in a changing world. Funct. Ecol. 2016, 30, 1109-1121. [CrossRef]

97. Jiang, Y.; Zhou, H.; Chen, L.; Yuan, Y.; Fang, H.; Luan, L.; Chen, Y.; Wang, X.; Liu, M.; Li, H.; et al. Nematodes and microorganisms interactively stimulate soil organic carbon turnover in the macroaggregates. Front. Microbiol. 2018, 9, 2803. [CrossRef] [PubMed]

98. Harkes, P.; Verhoeven, A.; Sterken, M.G.; Snoek, L.B.; Van den Elsen, S.J.; Mooijman, P.J.; Quist, C.W.; Vervoort, M.T.; Helder, J. The differential impact of a native and a non-native ragwort species (Senecioneae) on the first and second trophic level of the rhizosphere food web. Oikos 2017, 126, 1790-1803. [CrossRef]

99. Neher, D.A. Nematode communities in organically and conventionally managed agricultural soils. J. Nematol. 1999, 31, 142-154. [PubMed]

100. Tsiafouli, M.A.; Argyropoulou, M.D.; Stamou, G.P.; Sgardelis, S.P. Soil nematode biodiversity in organic and conventional agroecosystems of Northern Greece. Russ. J. Nematol. 2006, 14, 159-169.

101. Carrascosa, M.; Sánchez-Moreno, S.; Alonso-Prados, J.L. Effects of organic and conventional pesticides on plant biomass, nematode diversity and the structure of the soil food web. Nematology 2015, 17, 11-26. [CrossRef]

102. Matsushita, Y.; Bao, Z.; Kurose, D.; Okada, H.; Takemoto, S.; Sawada, A.; Nagase, H.; Takano, M.; Murakami, H.; Koitabashi, M.; et al. Community structure, diversity, and species dominance of bacteria, fungi, and nematodes from naturally and conventionally farmed soil: A case study on Japanese apple orchards. Org. Agric. 2015, 5, 11-28. [CrossRef]

103. Pokharel, R.; Marahatta, S.P.; Handoo, Z.A.; Chitwood, D.J. Nematode community structures in different deciduous tree fruits and grape in Colorado, USA and impact of organic peach and apple production practices. Eur. J. Soil Biol. 2015, 67, 59-68. [CrossRef]

104. Coyne, D.; Kidane, S. Nematode pathogens. In Diseases of Banana, Abacá and Enset, 2nd ed.; Jones, D., Ed.; CABI: Wallingford, UK, 2018; 632p.

105. Djigal, D.; Chabrier, C.; Duyck, P.F.; Achard, R.; Quénéhervé, P.; Tixier, P. Cover crops alter the soil nematode food web in banana agroecosystems. Soil Biol. Biochem. 2012, 48, 142-150. [CrossRef]

106. Poeydebat, C.; Tixier, P.; Chabrier, C.; de Bellaire, L.D.; Vargas, R.; Daribo, M.O.; Carval, D. Does plant richness alter multitrophic soil food web and promote plant-parasitic nematode regulation in banana agroecosystems? Appl. Soil Ecol. 2017, 117, 137-146. [CrossRef]

107. Rodríguez, A.; Muñoz, Y.; Pocasangre, L.E. Evaluation of free-living nematodes as indicators of soil quality in three banana production systems. Tierra Trop. Sostenibilidad Ambient. Soc. 2012, 8, 15-25.

108. Chauvin, C.; Dorel, M.; Villenave, C.; Roger-Estrade, J.; Thuries, L.; Risède, J.M. Biochemical characteristics of cover crop litter affect the soil food web, organic matter decomposition, and regulation of plant-parasitic nematodes in a banana field soil. Appl. Soil Ecol. 2015, 96, 131-140. [CrossRef]

109. Godefroid, M.; Tixier, P.; Chabrier, C.; Djigal, D.; Quénéhervé, P. Associations of soil type and previous crop with plant-feeding nematode communities in plantain agrosystems. Appl. Soil Ecol. 2017, 13, 63-70. [CrossRef]

110. Florence, A.M.; McGuire, A.M. Do diverse cover crop mixtures perform better than monocultures? A systematic review. Agron. J. 2020, 112, 3513-3534. [CrossRef]

111. Damour, G.; Garnier, E.; Navas, M.L.; Dorel, M.; Risede, J.M. Using functional traits to assess the services provided by cover plants: A review of potentialities in banana cropping systems. Adv. Agron. 2015, 134, 81-133. [CrossRef]

112. Tabarant, P.; Villenave, C.; Risede, J.M.; Roger-Estrade, J.; Thuries, L.; Dorel, M. Effects of four organic amendments on banana parasitic nematodes and soil nematode communities. Appl. Soil Ecol. 2011, 49, 59-67. [CrossRef]

113. Ferris, H.; Pocasangre, L.E.; Serrano, E.; Muñoz, J.; Garcia, S.; Perichi, G.; Martinez, G. Diversity and complexity complement apparent competition: Nematode assemblages in banana plantations. Acta Oecol. 2012, 40, 1-8. [CrossRef]

114. Moser, T.; Förster, B.; Frankenbach, S.; Marques, R.; Römbke, J.; Schmidt, P.; Höfer, H. Nematode assemblages in banana (Musa acuminata) monocultures and banana plantations with Juçara palms (Euterpe edulis) in the southern Mata Atlântica, Brazil. Nematology 2012, 14, 371-384. [CrossRef]

115. Caveness, F.E.; Badra, T. Control of Helicotylenchus multicinctus and Meloidogyne javanica in established plantain and nematode survival as influenced by rainfall. Nematropica 1980, 10, 10-14.

116. Plowright, R.; Dusabe, J.; Coyne, D.; Speijer, P. Analysis of the pathogenic variability and genetic diversity of the plant-parasitic nematode Radopholus similis on bananas. Nematology 2013, 15, 41-56. [CrossRef]

117. Coyne, D. Pre-empting plant-parasitic nematode losses on Musa spp. Acta Hortic. 2009, 828, 227-236. [CrossRef]

118. Lorenzen, J.; Tenkouano, A.; Bandyopadhyay, R.; Vroh, B.I.; Coyne, D.; Tripathi, L. The role of crop improvement in pest and disease management. Acta Hortic. 2009, 828, 305-314. [CrossRef]

119. Lorenzen, J.; Tenkouano, A.; Bandyopadhyay, R.; Vroh, B.; Coyne, D.; Tripathi, L. Overview of banana and plantain improvement in Africa: Past and future. Acta Hortic. 2010, 879, 595-604. [CrossRef]

120. Seshu Reddy, K.V.; Prasad, J.S.; Speijer, P.R.; Sikora, R.A.; Coyne, D.L. Distribution of plant-parasitic nematodes on Musa in Kenya. InfoMusa 2007, 16, 18-23.

121. Luambano, N.; Kashando, B.; Masunga, M.; Mwenisongole, A.; Mziray, M.; Mbaga, J.; Polini, R.; Mgonja, D. Status of Pratylenchus coffeae in banana-growing areas of Tanzania. Physiol. Mol. Plant Pathol. 2018, 105, 102-109. [CrossRef] [PubMed]

122. Mgonja, D.; Temu, G.; Mziray, M.; Kashando, B.; Mwenisongole, A.; Masunga, M.; Lyantagaye, S.; Luambano, N. Morphological and molecular identification of Pratylenchus goodeyi associated with banana in Tanzania. J. Nematol. 2019, 45, $265-278$. 
123. Anderson, J.P. Accelerated microbial degradation of nematicides and other plant protection chemicals. Nematropica 1989, 19,1 .

124. Kema, G.H.J. The pesticide reduction plan for banana. In XVII Annual International Reunion ACORBAT: Bananicultura: Um Negócio Sustentável; Soprano, E., Tcacenco, F.A., Lichtemberg, L.A., Silva, M.C., Eds.; ACORBAT: Joinville, Brazil, 2006 ; pp. 3-4.

125. Churchill, A.C.L. Mycosphaerella fijiensis, the black leaf streak pathogen of banana: Progress towards understanding pathogen biology and detection, disease development, and the challenges of control. Mol. Plant Pathol. 2011, 12, 307-328. [CrossRef]

126. Cabidochea, Y.-M.; Achardb, R.; Cattanc, P.; Clermont-Dauphina, C.; Massatd, F.; Sansouleta, J. Long-term pollution by chlordecone of tropical volcanic soils in the French West Indies: A simple leaching model accounts for current residue. Environ. Pollut. 2009, 157, 1697-1705. [CrossRef]

127. Anon. Recommended Classification of Pesticides by Hazard, and Guidelines to Classification; World Health Organization: Geneva, Switzerland, 2006; 78p.

128. Sikora, R.A.; Pocasangre, L.; Zum Felde, A.; Niere, B.; Tam, T.; Vu, T.T.; Dababat, A.A. Mutualistic endophytic fungi and in-planta suppressiveness to plant parasitic nematodes. Biol. Control 2008, 46, 15-23. [CrossRef]

129. Sikora, R.A.; Zum Felde, A.; Mendoza, A.; Menjivar, R.; Pocasangre, L. In planta suppressiveness to nematodes and long-term root health stability through biological enhancement-Do we need a cocktail? Acta Hortic. 2010, 879, 553-560. [CrossRef]

130. Zum Felde, A. Endophytes: Novel weapons in the IPM arsenal. In CGIAR SP-IPM Technical Innovation Brief No. 9; IITA: Ibadan, Nigeria, 2011.

131. Kaushal, M.; Swennen, R.; Mahuku, G. Unlocking the microbiome communities of banana (Musa spp.) under disease stressed (Fusarium wilt) and non-stressed conditions. Microorganisms 2020, 8, 443. [CrossRef]

132. Van der Veken, L.; Win, P.P.; Elsen, A.; Swennen, R.; De Waele, D. Susceptibility of banana intercrops for rhizobacteria, arbuscular mycorrhizal fungi and the burrowing nematode Radopholus similis. Appl. Soil Ecol. 2008, 40, 283-290. [CrossRef]

133. Milne, D.L.; Keetch, D.P. Some observations on the host plant relationships of Radopholus similis in Natal. Nematropica 1976, $6,13-17$.

134. Van Asten, P.J.A.; Wairegi, L.W.I.; Mukasa, D.; Uringi, N.O. Agronomic and economic benefits of coffee-banana intercropping in Uganda's smallholder farming systems. Agric. Syst. 2011, 104, 326-333. [CrossRef]

135. Köberl, M.; Dita, M.; Martinuz, A.; Staver, C.; Berg, G. Agroforestry leads to shifts within the gammaproteobacterial microbiome of banana plants cultivated in Central America. Front. Microbiol. 2015, 6, 91. [CrossRef]

136. Elsen, A.; Gervacio, D.; Swennen, R.; De Waele, D. AMF-induced biocontrol against plant parasitic nematodes in Musa sp.: A systemic effect. Mycorrhiza 2008, 18, 251-256. [CrossRef]

137. Olaniyi, M.O. Effects of mycorrhizal inoculant and organic mulches on nematode damage to cooking banana. J. Biol. Agric. Healthc. 2014, 19, 81-86.

138. Van der Veken, L. Potential of Dual-Purpose Intercrops for the Management of Pathogenic Nematodes and Beneficial Arbuscular Mycorrhizal Fungi and Root Nodulating Rhizobacteria in Banana-Based Cropping Systems. Ph.D. Thesis, Katholieke Universiteit Leuven, Leuven, Belgium, 2010.

139. Wairegi, L.W.I.; Van Asten, P.J.A. The agronomic and economic benefits of fertilizer and mulch use in highland banana systems in Uganda. Agric. Syst. 2010, 103, 543-550. [CrossRef]

140. Pattison, A.B.; Badcock, K.; Sikora, R.A. Influence of soil organic amendments on suppression of the burrowing nematode, Radopholus similis, on the growth of bananas. Australas. Plant Pathol. 2011, 40, 385-396. [CrossRef]

141. Gaidashova, S.V.; Van Asten, P.; De Waele, D.; Delvaux, B. Relationship between soil properties, crop management, plant growth and vigour, nematode occurrence and root damage in East African Highland banana-cropping systems: A case study in Rwanda. Nematology 2009, 883-894. [CrossRef]

142. Rotimi, M.O.; Speijer, P.; De Waele, D.; Swennen, R. Effect of mulching on the response of plantain cv. Agbagba (Musa spp., AAB-group) to plant parasitic nematodes in southeastern Nigeria. II. Reproductive growth. Niger. J. For. 2004, 34, $102-111$.

143. Olaniyi, M.O. Effects of organic mulches on the vegetative growth of plantain and nematode infection. Int. J. Nematol. 2008, $18,86-92$.

144. Coyne, D.; Rotimi, O.; Speijer, P.; De Schutter, B.; Dubois, T.; Auwerkerken, A.; Tenkouano, A.; De Waele, D. Effects of nematode infection and mulching on plantain (Musa spp., AAB-group) yield of ratoon cycles and plantation longevity in southeastern Nigeria. Nematology 2005, 7, 531-541. [CrossRef]

145. McIntyre, B.D.; Speijer, P.R.; Riha, S.J.; Kizito, F. Effect of mulching on biomass, nutrients and soil water in banana inoculated with nematodes. Agron. J. 2000, 92, 1081-1085. [CrossRef]

146. Viaene, N.; Coyne, D.L.; Davies, K. Biological and cultural control. In Plant Nematology, 2nd ed.; Perry, R.A., Moens, M., Eds.; CABI: Wallingford, UK, 2013; pp. 383-410.

147. Tenkouano, A.; Hauser, S.; Coyne, D.; Coulibaly, O. Clean planting materials and management practices for sustained production of banana and plantain in Africa. Chron. Hortic. 2006, 46, 14-18.

148. Stock, S.P. Diversity, biology and evolutionary relationships. In Nematode Pathogenesis of Insects and Other Pests-Ecology and Applied Technologies for Sustainable Plant and Crop Protection; Campos-Herrera, R., Ed.; Springer: Cham, Switzerland; Heidelberg, Germany; New York, NY, USA; Dordrecht, The Netherlands; London, UK, 2015; pp. 3-28.

149. Hussain, A.B.; Kumar, A.C.; Hassan, T.A. Global distribution of entomopathogenic nematodes, Steinernema and Heterorhabditis. Egypt. J. Biol. Pest Control 2020, 30, 31. [CrossRef] 
150. Hominick, W.M. Biogeography. In Entomopathogenic Nematology; Gaugler, R., Ed.; CABI Publishing: Wallingford, UK; New York, NY, USA, 2002; pp. 115-144.

151. San-Blas, E.; Campos-Herrera, R.; Dolinski, C.; Monteiro, C.; Andaló, V.; Garrigós Leite, L.; Rodríguez, M.G.; Morales-Montero, P.; Sáenz-Aponte, A.; Cedano, C.; et al. Entomopathogenic nematology in Latin America: A brief history, current research and future prospects. J. Invertebr. Pathol. 2019, 165, 22-45. [CrossRef]

152. Rodríguez, M.G. Entomopathogenic nematodes in Cuba: From laboratories to popular biological control agents for pest management in a developing country. In Nematode Pathogenesis of Insects and Other Pests-Ecology and Applied Technologies for Sustainable Plant and Crop Protection; Campos-Herrera, R., Ed.; Springer: Cham, Switzerland; Heidelberg, Germany; New York, NY, USA; Dordrecht, The Netherlands; London, UK, 2015; pp. 343-364. [CrossRef]

153. Touray, M.; Gulcu, B.; Ulug, D.; Gulsen, S.H.; Cimen, H.; Kaya, H.K.; Cakmak, I.; Hazir, S. Evaluation of different sponge types on the survival and infectivity of stored entomopathogenic nematodes. J. Invertebr. Pathol. 2020, 171, 1-15. [CrossRef]

154. Lewis, E.E.; Clarke, D.J. Nematode parasites and entomopathogens. In Insect Pathology, 2nd ed.; Vega, F.E., Kaya, H.K., Eds.; Academic Press: Cambridge, MA, USA, 2012; pp. 395-424. [CrossRef]

155. Stuart, R.J.; Gaugler, R. Patchiness in population of entomopathogenic nematodes. J. Invertebr. Pathol. 1994, 64, 39-45. [CrossRef]

156. Stuart, R.J.; Barbercheck, M.E.; Grewal, S.P. Entomopathogenic nematodes in the soil environment: Distribution, interactions and the influence of biotic and abiotic factors. In Nematode Pathogenesis of Insects and Other Pests-Ecology and Applied Technologies for Sustainable Plant and Crop Protection; Campos-Herrera, R., Ed.; Springer: Cham, Switzerland; Heidelberg, Germany; New York, NY, USA; Dordrecht, The Netherlands; London, UK, 2015; pp. 97-138. [CrossRef]

157. Lewis, E.E.; Hazir, S.; Hoodson, A.; Gulcu, B. Trophic relationships of entomopathogenic nematodes in agricultural habitats. In Nematodes Pathogenesis of Insect and Other Pest: Ecology and Applied Technologies for Sustainable Plant and Crop Protection; CamposHerrera, R., Ed.; Springer: Cham, Switzerland; Heidelberg, Germany; New York, NY, USA; Dordrecht, The Netherlands; London, UK, 2015; pp. 139-163. [CrossRef]

158. Campos-Herrera, R.; El-Borai, F.E.; Duncan, L.W. Wide interguild relationships among entomopathogenic and free-living nematodes in soil as measured by real time qPCR. J. Invertebr. Pathol. 2012, 111, 126-135. [CrossRef]

159. Campos-Herrera, R.; Pathak, E.; El-Borai, F.E.; Stuart, R.J.; Gutiérrez, C.; Rodríguez-Martín, J.A.; Graham, J.H.; Duncan, L.W. Geospatial patterns of soil properties and the biological control potential of entomopathogenic nematodes in Florida citrus groves. Soil Biol. Biochem. 2013, 66, 163-174. [CrossRef]

160. Duncan, L.W.; Dunn, D.C.; Bague, G.; Nguyen, K. Competition between entomopathogenic and free-living bactivorous nematodes in larvae of the weevil Diaprepes abbreviatus. J. Nematol. 2003, 35, 187-193.

161. Kawaka, F.J.; Kimenju, J.W.; Ayodo, G.; Mwaniki, S.W.; Muoma, J.O.; Okoth, S.A.; Orinda, G.O. Impact of land use on the distribution and diversity of entomopathogenic nematodes in Embu and Taita districts, Kenya. Trop. Subtrop. Agroecosyst. 2011, 13, 59-63.

162. Franco-Navarro, F.; Godinez-Vidal, D. Soil nematodes associated with different land uses in the Los Tuxtlas Biosphere Reserve, Veracruz, Mexico. Rev. Mex. Biodiv. 2017, 88, 136-145. [CrossRef]

163. Campos-Herrera, R.; Escuer, M.; Labrador, S.; Gutiérrez, C. Aislamiento, identificación y caracterización ecológica de nematodos entomopatógenos de La Rioja. Zúbia 2006, 23-24, 27-56.

164. Leah, M.C.; Barbercheck, M.E. Effects of tillage practices on entomopathogenic nematodes in a corn agroecosystem. Biol. Control 2001, 25, 1-11. [CrossRef]

165. Barker, C.W.; Barker, G.M. Generalist entomopathogens as biological indicators of deforestation and agricultural land use impacts on Waikato Soils. N. Z. J. Ecol. 1998, 22, 189-196.

166. Nagesh, M.; Askary, T.H.; Manohar, B.; Aracalagud, N.S.; Rajan. Strategies for making entomopathogenic nematodes cost-effective biological control agents. In Biocontrol Agents; Entomopathogenic Nematodes and Slug Parasitic Nematodes; Abd-Elgawad, M.M.M., Asky, T.H., Coupland, J., Eds.; CAB International: Oxfordshire, UK; Boston, MA, USA, 2017; pp. 596-611. [CrossRef]

167. Saleh, M.M.E.; Hala, M.S.M.; Abonaem, M. Commercialization of biopesticides based on entomopathogenic nematodes. In Cottage Industry of Biocontrol Agents and Their Applications; Practical Aspects to Deal Biologically with Pests and Stresses Facing Strategic Crops; El-Wakeil, N., Saleh, M., Abu-Hashim, M., Eds.; Springer Nature: Cham, Switzerland, 2020; pp. 253-275. [CrossRef]

168. Robinson, J.C.; Galán Saúco, V. Bananas and Plantains, 2nd ed.; CAB International: Wallingford, UK; Cambridge, MA, USA, 2010; pp. 233-244.

169. Gaugler, R. Ecological considerations in the biological control of soil-inhabiting insects with entomopathogenic nematodes. Agric. Ecosyst. Environ. 1988, 24, 351-360. [CrossRef]

170. Treverrow, N.L.; Bedding, R.A. Development of a system for the control of the banana weevil borer, Cosmopolites sordidus, with entomopathogenic nematodes. In Nematodes and the Biological Control of Insect Pests; Bedding, R., Akhurst, R., Kaya, H.K., Eds.; CSIRO: Melbourne, Australia, 1993; pp. 41-47.

171. Miranda, I.; García-Perera, D.; Rodríguez, M.G. Meta-análisis de las estrategias para el manejo de Cosmopolitis sordidus Guermar en Musa spp. Rev. Prot. Veg. 2019, 34,1-7.

172. Sepúlveda-Cano, P.A.; López-Núñez, J.C.; Soto-Giraldo, A. Efecto de dos nematodos entomopatógenos sobre Cosmopolites sordidus (Coleoptera: Dryophthoridae). Rev. Colomb. Entomol. 2008, 34, 62-67. 
173. Figueroa, W.; Román, J.; Acosta, M.A. Isolates of entomogenous nematodes Heterorhabditis spp. and mortality of larvae of Galleria mellonella, Cylas formicarius, Euscepes postfasciatus and Cosmopolites sordidus. J. Agric. Univ. P. R. 1993, 77, 53-60. [CrossRef]

174. Schmitt, A.T.; Gowen, S.R.; Hague, G.M. A baiting technique for the control of Cosmopolites sordidus Germar (Coleoptera: Curculionidae) by Steinernema carpocapsae (Nematoda: Steinernematidae). Nematropica 1992, 22, 159-163.

175. Smith, D. Banana weevil borer control in south-eastern Queensland. Aust. J. Exp. Agric. 1995, 35, 1165-1172. [CrossRef]

176. Rosales, L.C.; Suárez, Z. Nematodos entomopatógenos como posibles agentes de control del gorgojo negro del plátano Cosmopolites sordidus (Germar 1824) (Coleoptera: Curculionidae). Bol. Entomol. Venez. 1998, 13, 123-140.

177. Chabrier, C.; Mauléon, H.; Quénéhervé, P. Combination of Steinernema carpocapsae (Weiser) and pheromone lure: A promising strategy for biological control of the banana black weevil Cosmopolites sordidus (Germar) on bananas in Martinique. Nematology 2002, 4, 190-191.

178. Padilla-Cubas, Á.; Carnero, A.H.; García del Pino, F. Laboratory efficacy against neonate larvae of the banana weevil Cosmopolites sordidus of two indigenous entomopathogenic nematode species from the Canary Islands (Spain). Int. J. Pest Manag. 2010, 56, 211-216. [CrossRef]

179. Bortoluzzi, L.; Alves, L.F.A.; Alves, V.S.; Holz, N. Entomopathogenic nematodes and their interaction with chemical insecticide aiming at the control of banana weevil borer, Cosmopolites sordidus Germar (Coleoptera: Curculionidae). Arq. Inst. Biol. 2013, 80, 183-192. [CrossRef]

180. Amador, M.; Molina, D.; Guillen, C.; Parajeles, E.; Jiménez, K.; Uribe, L. Utilización del nematodo entomopatógeno Heterorhabditis atacamensis CIA-NE07 en el control del picudo del banano Cosmopolites sordidus en condiciones in vitro. Agron. Cost. 2015, 39, 47-60.

181. Moses, M.N.; Kilalo, D.; Kimenju, W.J.; Mwaniki, S.W. Pathogenicity of selected Kenyan entomopathogenic nematodes of genus Steinernema against banana weevil (Cosmopolites sordidus). J. Sci. Food Agric. 2016, 3, 29-36. [CrossRef]

182. Kutnjem, D.; Bekolo, N.; Zachée, A.; Mounpoubeyi, N.M.; Zemko, P.N.; Tongue, T. Sensibilité des charançons (Cosmopolites sordidus) du Bananier (Musa sp.) aux nématodes entomopathogénes de la famille des Heterorhabditidae. Am. J. Innov. Res. Appl. Sci. 2017, 5, 19-25.

183. García-Perera, D.; Enrique, R.; López, L.; Hernández-Ochandía, D.; Miranda, I.; Calabuche-Gómez, G.; Pino, O.; Pupiro, L.; Rodríguez, M.G. Susceptibilidad de adultos de Cosmopolites sordidus (Germar) a Heterorhabditis amazonensis Andaló et al. cepa HC1. Rev. Prot. Veg. 2019, 34, 1-8.

184. Griffin, C.T.; Chaerani, R.; Fallon, D.; Reid, A.P.; Downes, M.J. Occurrence and distribution of the entomopathogenic nematodes Steinernema spp. and Heterorhabditis indica in Indonesia. J. Helminthol. 2000, 74, 143-150. [CrossRef] [PubMed]

185. Stock, S.P.; Griffin, C.T.; Chaerani, R. Morphological and molecular characterisation of Steinernema hermaphroditum n. sp. (Nematoda:Steinernematidae), an entomopathogenic nematode from Indonesia, and its phylogenetic relationships with other members of the genus. Nematology 2004, 6, 401-412. [CrossRef]

186. Hatting, J.; Stock, S.P.; Hazir, S. Diversity and distribution of entomopathogenic nematodes (Steinernematidae, Heterorhabditidae) in South Africa. J. Invertebr. Pathol. 2009, 102, 120-128. [CrossRef]

187. Shahina, F.; Tabassum, K.A. Steinernema carpocapsae (Nematoda: Steinernematidae), a new entomopathogenic nematode isolate from Pakistan. Pak. J. Nematol. 2010, 28, 59-64.

188. Mwaitulo, S.; Haukeland, S.; Sæthre, M.-G.; Laudisoit, A.; Maerere, A.P. First report of entomopathogenic nematodes from Tanzania and their virulence against larvae and adults of the banana weevil Cosmopolites sordidus (Coleoptera: Curculionidae). Int. J. Trop. Insect Sci. 2011, 31, 154-161. [CrossRef]

189. Razia, M.; Padmanaban, R.; Karthik, R.R.; Chellapandi, P.; Sivaramakrishnan. Monitoring entomopathogenic nematodes as ecological indicators in the cultivated lands of Karur District, Tamil Nadu: A survey report. Electron. J. Biol. 2011, 7, 16-19.

190. Seenivasan, N.; Prabhu, S.; Makesh, S.; Sivakumar, M. Natural occurrence of entomopathogenic nematode species (Rhabditida: Steinernematidae and Heterorhabditidae) in cotton fields of Tamil Nadu, India. J. Nat. Hist. 2012, 46, 2829-2843. [CrossRef]

191. Morales, N.; Morales-Montero, P.; Puza, V.; San-Blas, E. First Report of Heterorhabditis amazonensis from Venezuela and characterization of three populations. J. Nematol. 2016, 48, 139-147. [CrossRef] [PubMed]

192. Noujeim, E.; Sakr, J.; Fanelli, E.; Troccoli, A.; Pages, S.; Tarasco, E.; De Luca, F. Phylogenetic relationships of entomopathogenic nematodes and their bacterial symbionts from coastal areas in Lebanon. REDIA 2016, 99, 127-137. [CrossRef]

193. Puza, V.; Mrácek, Z. Seasonal dynamics of entomopathogenic nematodes of the genera Steinernema and Heterorhabditis as a response to abiotic factors and abundance of insect hosts. J. Invertebr. Pathol. 2005, 89, 116-122. [CrossRef] [PubMed]

194. Xun, Y.; Waweru, B.; Xuehong, Q.; Hategekimana, A.; Kajuga, J.; Hongmei, L.; Edgington, S.; Umulisa, C.; Richou, H.; Toepfer, S. New entomopathogenic nematodes from semi-natural and small-holder farming habitats of Rwanda. Biocontrol Sci. Technol. 2016, 26, 820-834. [CrossRef]

195. Campos-Herrera, R.; Gómez-Ros, J.M.; Escuer, M.; Cuadra, L.; Barrios, L.; Gutiérrez, C. Diversity, occurrence, and life characteristics of natural entomopathogenic nematode populations from La Rioja (Northern Spain) under different agricultural management and their relationships with soil factors. Soil Biol. Biochem. 2008, 40, 1474-1484. [CrossRef]

196. Hummel, R.L.; Walgenbach, J.F.; Barbercheck, M.E.; Kennedy, G.G.; Hoyt, G.D.; Arellano, C. Effects of production practices on soil-borne entomopathogens in western North Carolina vegetable systems. Environ. Entomol. 2002, 31, 84-91. [CrossRef] 
197. Leite, L.G.; Schmidt, F.S.; Harakava, R.; Filho, A.B.; Giometti, F.H.C.; Pietrobon, T.C.; Chacon-Orozco, J. The influence of mulch on the persistence of Steinernema brazilense (Nematoda: Steinernematidae) in sugarcane fields. Rev. Colomb. Entomol. 2015, $41,176-179$.

198. Shapiro-Ilan, D.; Obrycki, J.J.; Lewis, L.C.; Jackson, J.J. Effects of crop residue on the persistence of Steinernema carpocapsae. J. Nematol. 1999, 31, 517-519.

199. Rodrigues, R.S.D.; Aguillera, M.M.; Gobbi, N.; Pizano, M.A. Influencia de diferentes doses de torta de filtro no solo sobre migracao e persistencia de Steinernema glaseri Steiner, 1929 (Nematoda:Rhabditidae). Holos Environ. 2005, 5, 52-64. [CrossRef]

200. Hummer, K.E.; Janick, J. Rosaceae: Taxonomy, economic importance, genomics. In Genetics and Genomics of Rosaceae; Springer: New York, NY, USA, 2009; pp. 1-17. [CrossRef]

201. Birkhofer, K.; Addison, M.F.; Arvidsson, F.; Bazelet, C.; Bengtsson, J.; Booysen, R.; Conlong, D.; Haddad, C.; Janion-Scheepers, C.; Kapp, C.; et al. Effects of ground cover management on biotic communities, ecosystem services and disservices in organic deciduous fruit orchards in South Africa. Front. Sustain. Food Syst. 2019, 3, 107. [CrossRef]

202. Samnegård, U.; Alins, G.; Boreux, V.; Bosch, J.; García, D.; Happe, A.K.; Klein, A.M.; Miñarro, M.; Mody, K.; Porcel, M.; et al. Management trade-offs on ecosystem services in apple orchards across Europe: Direct and indirect effects of organic production. J. Appl. Ecol. 2019, 56, 802-811. [CrossRef]

203. Reganold, J.P.; Glover, J.D.; Andrews, P.K.; Hinman, H.R. Sustainability of three apple production systems. Nature 2001, 410, 926-930. [CrossRef]

204. Castellano-Hinojosa, A.; Strauss, S.L. Impact of cover crops on the soil microbiome of tree crops. Microorganisms 2020, $8,328$. [CrossRef]

205. Rodríguez, J.P.; Beard, T.D.; Bennett, E.M.; Cumming, G.S.; Cork, S.J.; Agard, J.; Dobson, A.P.; Peterson, G.D. Trade-offs across space, time, and ecosystem services. Ecol. Soc. 2006, 11, 28. [CrossRef]

206. Kapp, C.; Storey, S.G.; Malan, A.P. Organic vs conventional: Soil nematode community structure and function. Commun. Agric. Appl. Biol. Sci. 2014, 79, 297-300. [PubMed]

207. Pokharel, R.R.; Zimmerman, R. Impact of organic and conventional peach and apple production practices on soil microbial populations and plant nutrients. Org. Agric. 2016, 6, 19-30. [CrossRef]

208. Forge, T.A.; Hogue, E.; Neilsen, G.; Neilsen, D. Effects of organic mulches on soil microfauna in the root zone of apple: Implications for nutrient fluxes and functional diversity of the soil food web. Appl. Soil Ecol. 2003, 22, 39-54. [CrossRef]

209. Forge, T.; Neilsen, G.; Neilsen, D.; O'Gorman, D.; Hogue, E.; Angers, D. Organic orchard soil management practices affect soil biology and organic matter. In II International Symposium on Organic Matter Management and Compost Use in Horticulture. Acta Hortic. 2015, 1076, 77-84. [CrossRef]

210. Kanfra, X.; Liu, B.; Beerhues, L.; Sørensen, S.J.; Heuer, H. Free-living nematodes together with associated microbes play an essential role in apple replant disease. Front. Plant Sci. 2018, 16, 1666. [CrossRef] [PubMed]

211. Mazzola, M.; Manici, L.M. Apple replant disease: Role of microbial ecology in cause and control. Ann. Rev. Phytopathol. 2012, 50, 45-65. [CrossRef] [PubMed]

212. Winkelmann, T.; Smalla, K.; Amelung, W.; Baab, G.; Grunewaldt-Stöcker, G.; Kanfra, X.; Meyhöfer, R.; Reim, S.; Schmitz, M.; Vetterlein, D.; et al. Apple replant disease: Causes and mitigation strategies. Curr. Issues Mol. Biol. 2019, 30, 89-106. [CrossRef] [PubMed]

213. Tewoldemedhin, Y.T.; Mazzola, M.; Labuschagne, I.; McLeod, A. A multi-phasic approach reveals that apple replant disease is caused by multiple biological agents, with some agents acting synergistically. Soil Biol. Biochem. 2011, 43, 1917-1927. [CrossRef]

214. Jaffee, B.A.; Abawi, G.S.; Mai, W.F. Role of soil microflora and Pratylenchus penetrans in an apple replant disease. Phytopathology 1982, 72, 247-251. [CrossRef]

215. Lemanceau, P.; Maron, P.A.; Mazurier, S.; Mougel, C.; Pivato, B.; Plassart, P.; Ranjard, L.; Revellin, C.; Tardy, V.; Wipf, D. Understanding and managing soil biodiversity: A major challenge in agroecology. Agron. Sustain. Dev. 2015, 35, 67-81. [CrossRef] 